\title{
In Situ Spectroscopic Investigation of Molecular Structures of Highly Dispersed Vanadium Oxide on Silica under Various Conditions
}

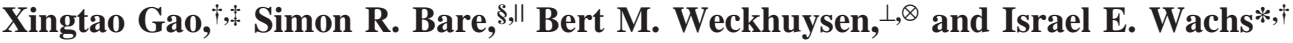 \\ Department of Chemistry and Chemical Engineering, Zettlemoyer Center for Surface Studies, \\ Lehigh University, 7 Asa Drive, Bethlehem, Pennsylvania 18015, UOP Research, \\ Des Plaines, Illinois 60017, and Centrum voor Oppervlaktechemie en Katalyse, K. U. Leuven, \\ Kardinaal Mercierlaan 92, B-3001 Heverlee, Belgium
}

Received: June 16, 1998; In Final Form: September 11, 1998

\begin{abstract}
The molecularly dispersed $\mathrm{V}_{2} \mathrm{O}_{5} / \mathrm{SiO}_{2}$ supported oxides were prepared by the incipient wetness impregnation of 2-propanol solutions of $\mathrm{V}$-isopropoxide. The experimental maximum dispersion of surface vanadium oxide species on $\mathrm{SiO}_{2}$ was achieved at $\sim 12 \mathrm{wt} \% \mathrm{~V}_{2} \mathrm{O}_{5}\left(\sim 2.6 \mathrm{~V}\right.$ atoms $\left./ \mathrm{nm}^{2}\right)$. The surface structures of the molecularly dispersed $\mathrm{V}_{2} \mathrm{O}_{5} / \mathrm{SiO}_{2}$ samples under various conditions were extensively investigated by in situ Raman, UVvis-NIR DRS and XANES spectroscopies. The combined characterization techniques revealed that in the dehydrated state only isolated $\mathrm{VO}_{4}$ species are present on the silica surface up to monolayer coverage. Interestingly, the three-member siloxane rings on the silica surface appear to be the most favorable sites for anchoring the isolated, three-legged $(\mathrm{SiO})_{3} \mathrm{~V}=\mathrm{O}$ species. Hydration dramatically changes the molecular structure of the surface vanadium oxide species. The specific structure of the hydrated surface vanadium oxide species is dependent on the degree of hydration. The molecular structure of the fully hydrated vanadium oxide species closely resembles $\mathrm{V}_{2} \mathrm{O}_{5} \cdot n \mathrm{H}_{2} \mathrm{O}$ gels, rather than $\mathrm{V}_{2} \mathrm{O}_{5}$ crystallites. The fully hydrated surface vanadium oxide species are proposed to be chain and/or two-dimensional polymers with highly distorted square-pyramidal $\mathrm{VO}_{5}$ connected by $\mathrm{V}-\mathrm{OH}-\mathrm{V}$ bridges, which are stabilized on the silica surface by the sixth neighbor of $\mathrm{Si}-\mathrm{OH}$ hydroxyls via $\mathrm{Si}-\mathrm{OH} \cdots \mathrm{V}$ hydrogen bonds. In analogy to the hydration process, alcoholysis occurs during methanol chemisorption, and similar molecular structures are proposed to interpret the interaction between methanol molecules and the surface vanadium oxide species on silica.
\end{abstract}

\section{Introduction}

Silica-supported vanadium oxides have attracted much attention in recent years because of their unique structural and catalytic properties. $\mathrm{V}_{2} \mathrm{O}_{5} / \mathrm{SiO}_{2}$ catalysts are one of the most selective catalysts for methane oxidation to formaldehyde ${ }^{1,2}$ and are also very selective for oxidative dehydrogenation of ethane to ethylene. ${ }^{3}$ In addition, $\mathrm{V}_{2} \mathrm{O}_{5} / \mathrm{SiO}_{2}$ catalysts exhibit high activities and selectivities for photooxidation of alcohols ${ }^{4}$ and hydrocarbons. ${ }^{5} \quad \mathrm{~V}_{2} \mathrm{O}_{5} / \mathrm{SiO}_{2}$ catalysts have also been examined for other reactions, including the photocatalytic isomerization of trans-2-butene, ${ }^{6}$ the catalytic oxidation of toluene, ${ }^{7} n$-butene oxidation reactions, ${ }^{8}$ and the oxidation of benzene to phenol. ${ }^{9}$

Extensive studies have been conducted to determine molecular structures of the dispersed surface vanadium oxide species on the silica support in order to understand their physicochemical and catalytic properties. Various techniques have been used, including FTIR ${ }^{7,10,11 b}$ and Raman spectroscopy, ${ }^{10,11 \mathrm{c}, 12-14}$ XPS,, $11 \mathrm{c}$ solid-state ${ }^{51} \mathrm{~V}$ NMR, ${ }^{12}$ the $\mathrm{V}$ K-edge EXAFS/XANES, ${ }^{11 \mathrm{a}, 15}$ UV-vis DRS, ${ }^{7,8,10,16}$ and luminescence spectroscopy. ${ }^{6,17}$ The literature results are briefly summarized below and are grouped by the experimental conditions employed by various authors:

* To whom correspondence should be addressed. E-mail: iew0@ lehigh.edu.

Lehigh University.

+E-mail: xig2@1ehigh.edu.

$\S$ UOP Research.

"E-mail: SRBARE@uop.com.

$\perp$ K. U. Leuven.

${ }^{\otimes}$ E-mail: Bert.Weckhuysen@agr.kuleuven.ac.be. (i) Dehydrated State. It is generally accepted that at low vanadia loadings $\left(<5 \mathrm{wt} \% \mathrm{~V}_{2} \mathrm{O}_{5}\right)$ the surface vanadium oxide species are isolated $\mathrm{VO}_{4}$ units. ${ }^{6,7,11-13,15-17}$ However, contradictory conclusions are obtained at higher vanadia loadings. Arena et al. ${ }^{16}$ proposed that the di- or oligomeric $\mathrm{VO}_{4}$ structures are present on the $5 \% \mathrm{~V}_{2} \mathrm{O}_{5} / \mathrm{SiO}_{2}$ catalyst and that $2 \mathrm{D}$ patches of pentacoordinated vanadium ions exist on the $20 \% \mathrm{~V}_{2} \mathrm{O}_{5} / \mathrm{SiO}_{2}$ catalyst on the basis of their UV-vis DRS studies. Jonson et al. ${ }^{7}$ suggest the presence of polyvanadium chains on silica on the basis of the red shift of the ligand-to-metal charge transfer (LMCT) band in the UV-vis DRS spectra with increasing vanadia concentration. Inumaru et al. ${ }^{11}$ assumed the formation of thin overlayers of $\mathrm{V}_{2} \mathrm{O}_{5}$ on $\mathrm{SiO}_{2}$ by using the CVD (chemical vapor deposition) preparation method. Results from Raman and $\mathrm{UV}$ - vis DRS spectroscopy allowed Wokaun et al. ${ }^{10}$ to propose that three main types of surface vanadium oxide species are present on silica: monomeric and oligomeric species possessing a $\mathrm{VO}_{4}$ coordination geometry and ribbons of limited lateral extent with a square pyramid coordination geometry. In contrast, on the basis of both ${ }^{51} \mathrm{~V}$ NMR and Raman spectroscopy results, Das et al. ${ }^{12}$ concluded that the dispersed surface vanadium oxide species on silica, even at a high loading of 10 wt $\% \mathrm{~V}_{2} \mathrm{O}_{5}$, possess predominantly isolated $\mathrm{VO}_{4}$ structure regardless of the vanadia loading.

(ii) Hydrated State. The molecular structure of dispersed $\mathrm{V}_{2} \mathrm{O}_{5} / \mathrm{SiO}_{2}$ catalysts is much less understood as compared to the dehydrated state because the extent of hydration was not the same in all studies. Yoshida et al. ${ }^{15}$ studied the effect of 
hydration on the molecular structure of the dehydrated $2.8 \%$ $\mathrm{V}_{2} \mathrm{O}_{5} / \mathrm{SiO}_{2}$ catalyst by XANES/EXAFS spectroscopy, and the local structure of $\mathrm{V}(\mathrm{V})$ was found to change upon hydration. They assumed that the adsorption of water molecules produces a polymeric array of $\mathrm{VO}_{4}$ units bridged by two $\mathrm{H}_{2} \mathrm{O}$ molecules per unit. This structure is somewhat speculative because the authors did not consider the hydrolysis of the bridging $\mathrm{V}-\mathrm{O}-$ $\mathrm{Si}$ bonds by water molecules, which is responsible for the instability of the surface vanadium oxide species on the silica support as will be shown later. Went et al. ${ }^{13}$ studied the hydration effect by Raman spectroscopy. They proposed that the hydrated structure of the dispersed surface vanadium oxide species on $\mathrm{SiO}_{2}$ is composed of isolated $\mathrm{VO}_{4}$ unit with one $\mathrm{V}-\mathrm{OH}$ formed from hydrolysis of the $\mathrm{V}-\mathrm{O}-\mathrm{Si}$ bond. However, different Raman spectra of the hydrated $\mathrm{V}_{2} \mathrm{O}_{5} / \mathrm{SiO}_{2}$ catalysts have been reported by other authors, ${ }^{12,18}$ which may be related to the degree of hydration. A luminescence spectroscopic study by Hazenkamp and Blasse ${ }^{17}$ suggested that the hydrated vanadium oxide species might be decavanadate complexes. However, the close resemblance of Raman and ${ }^{51} \mathrm{~V}$ NMR spectra between the hydrated $\mathrm{V}_{2} \mathrm{O}_{5} / \mathrm{SiO}_{2}$ catalysts and $\mathrm{V}_{2} \mathrm{O}_{5}$ crystallites allowed Das et al. ${ }^{12}$ to conclude that the hydrated vanadium oxide species on silica are hydrated amorphous $\mathrm{V}_{2} \mathrm{O}_{5}$-like clusters, rather than decavanadate-like species. In summary, the detailed molecular structure of the hydrated $\mathrm{V}_{2} \mathrm{O}_{5} / \mathrm{SiO}_{2}$ catalysts is far from clear in the literature.

The preparation method could largely affect the dispersion of vanadium oxide species on the silica support since silica is relatively inert compared to other oxide supports (e.g., $\mathrm{Al}_{2} \mathrm{O}_{3}$, $\mathrm{TiO}_{2}$ ). The poor dispersion can limit the thorough understanding of the molecular structure of the surface vanadium oxide owing to its low concentration as well as the possible interference from the signal of $\mathrm{V}_{2} \mathrm{O}_{5}$ crystallites. For chemical modification of silica, the surface hydroxyls generally act as the adsorptive/ reactive sites because of their hydrophilic character. Thus, the preparation of highly dispersed metal oxides on silica by either impregnation or chemical vapor deposition often involves a highly reactive $\mathrm{H}$-sequestering precursor, such as $\mathrm{V}$-alkoxides, which will readily react with the surface hydroxyls of the silica support. ${ }^{12,19,20}$ The aqueous impregnation method with $\mathrm{NH}_{4} \mathrm{VO}_{3}$ as the precursor usually results in a low dispersion $(<5 \mathrm{wt} \%$ $\left.\mathrm{V}_{2} \mathrm{O}_{5}\right) .{ }^{10,13,14,16,18}$ On the other hand, the CVD method with $\mathrm{V}$-ethoxide as the precursor may result in thin overlayers of $\mathrm{V}_{2} \mathrm{O}_{5}$ on $\mathrm{SiO}_{2}$ with polymerized $\mathrm{V}-\mathrm{O}-\mathrm{V}$ bonds. ${ }^{11}$ In this work, the incipient wetness impregnation of 2-propanol solutions of $\mathrm{V}$-isopropoxide was employed to prepare highly dispersed $\mathrm{V}_{2} \mathrm{O}_{5} /$ $\mathrm{SiO}_{2}$ catalysts. Various parameters that affect the dispersion capacity of metal oxides on silica have been carefully considered, ${ }^{19}$ which allowed us to achieve the maximum surface coverage of $\sim 12 \% \mathrm{~V}_{2} \mathrm{O}_{5}\left(\sim 2.6 \mathrm{~V}\right.$ atoms $\left./ \mathrm{nm}^{2}\right)$ on $\mathrm{SiO}_{2}\left(S_{\mathrm{BET}}=\right.$ $\left.332 \mathrm{~m}^{2} / \mathrm{g}\right)$.

The molecular structure of surface vanadium oxide species is a strong function of environmental conditions; therefore, a well-controlled environmental condition is crucial to investigate and understand the behavior of the dispersed vanadium oxide species on the silica support. The present investigation focuses on the in situ molecular structural characterization of the highly dispersed $\mathrm{V}_{2} \mathrm{O}_{5} / \mathrm{SiO}_{2}$ system under various conditions (i.e., hydration, dehydration, methanol chemisorption/oxidation reaction) with combined Raman, UV-vis-NIR DRS and XANES spectroscopies. The structural information derived from these in situ spectroscopic studies provides fundamental understanding about the interaction of vanadium oxide with the silica surface.

\section{Experimental Section}

1. Catalyst Preparation. The silica support used for this study was Cabosil EH-5. This fluffy material was pretreated with water in order to condense its volume for easier handling. The wet $\mathrm{SiO}_{2}$ was dried at $120^{\circ} \mathrm{C}$ and subsequently calcined at $500{ }^{\circ} \mathrm{C}$ overnight.

The $\mathrm{V}_{2} \mathrm{O}_{5} / \mathrm{SiO}_{2}$ supported oxide catalysts were prepared by the incipient-wetness impregnation of 2-propanol solutions of vanadium isopropoxide $\left(\mathrm{VO}\left(\mathrm{O}-\mathrm{Pr}^{\mathrm{i}}\right)_{3}\right.$, Alfa-Aesar $97 \%$ purity). The preparation was performed inside a glovebox with continuously flowing $\mathrm{N}_{2}$. The $\mathrm{SiO}_{2}$ support was initially dried at 120 ${ }^{\circ} \mathrm{C}$ to remove the physisorbed water before impregnation. After impregnation, the samples were kept inside the glovebox with flowing $\mathrm{N}_{2}$ overnight. The samples were subsequently dried in flowing $\mathrm{N}_{2}$ at $120^{\circ} \mathrm{C}$ for $1 \mathrm{~h}$ and $300{ }^{\circ} \mathrm{C}$ for $1 \mathrm{~h}$. Then, the samples were calcined in flowing air at $300^{\circ} \mathrm{C}$ for $1 \mathrm{~h}$ and 450 ${ }^{\circ} \mathrm{C}$ for $2 \mathrm{~h}$. A two-step preparation procedure was employed to prepare 12 and 15 wt $\% \mathrm{~V}_{2} \mathrm{O}_{5}$ samples. The second impregnation followed the same procedure described above by using $8 \% \quad \mathrm{~V}_{2} \mathrm{O}_{5} / \mathrm{SiO}_{2}$ as the starting material. The actual compositions of the $\mathrm{V}_{2} \mathrm{O}_{5} / \mathrm{SiO}_{2}$ catalysts were determined by atomic absorption on a Perkin-Elmer system after samples were dissolved in HF solutions.

The BET surface area of each sample was measured by nitrogen adsorption/desorption isotherms on a Micromeritics ASAP 2000.

2. Raman Spectroscopy. Raman spectra of the hydrated and dehydrated samples were obtained in the $100-1200 \mathrm{~cm}^{-1}$ region with the $514.5 \mathrm{~nm}$ line of an $\mathrm{Ar}^{+}$ion laser (Spectra Physics, model 164). The scattered radiation from the sample was directed into an OMA III (Princeton Applied Research, model 1463) optical multichannel analyzer with a photodiode array cooled thermoelectrically to $-35^{\circ} \mathrm{C}$. The samples were pressed into self-supporting wafers. The Raman spectra of the hydrated samples were collected during rotating the sample under ambient conditions. The Raman spectra of the dehydrated samples were recorded at room temperature and were obtained after heating the sample in flowing $\mathrm{O}_{2}$ at $450-500{ }^{\circ} \mathrm{C}$ for $1 \mathrm{~h}$ in a stationary quartz cell.

The in situ Raman spectra during methanol oxidation were collected in both 600-1100 and 2700-3100 $\mathrm{cm}^{-1}$ regions on a second Raman apparatus (same as above). A self-supporting sample disk of 100-200 mg was mounted on the sample holder, which is capable of spinning inside a quartz cell. The in situ Raman cell setup is described in detail elsewhere. ${ }^{21}$ The sample in the cell was heated at $500{ }^{\circ} \mathrm{C}$ for $1 \mathrm{~h}$ in a flowing $\mathrm{O}_{2} / \mathrm{He}$ mixture (Linde Specialty Gas, $\mathrm{O}_{2}, 99.99 \%$ purity; He, ultrahigh purity). The background Raman spectrum was taken after the sample was cooled to $230{ }^{\circ} \mathrm{C}$. Then, methanol vapor was introduced by passing the $\mathrm{O}_{2} / \mathrm{He}$ mixture through liquid methanol in an ice bath $\left(\sim 4 \mathrm{~mol} \% \mathrm{CH}_{3} \mathrm{OH}\right.$ in the saturated gaseous mixture). The Raman spectra under reaction conditions were obtained after reaching steady state $\left(\sim 30 \mathrm{~min}\right.$ at $\left.230{ }^{\circ} \mathrm{C}\right)$. The Raman spectra after removal of methanol from the feed stream as well as at a higher temperature of $300{ }^{\circ} \mathrm{C}$, with/without methanol in the feed gas, were also recorded in order to examine the stability of the chemisorbed species.

3. UV-Vis-NIR Diffuse Reflectance Spectroscopy. Diffuse reflectance spectra (DRS) in the range of 200-2200 nm were taken on a Varian Cary 5E UV-vis-NIR spectrophotometer. The spectra were recorded against a halon white reflectance standard as the baseline. The computer processing of the spectra with Bio-Rad Win-IR software consisted of conversion of wavelength (nm) to wavenumber $\left(\mathrm{cm}^{-1}\right)$ and calculation of 
TABLE 1: Surface Areas and Compositions of $\mathrm{V}_{2} \mathrm{O}_{5} / \mathrm{SiO}_{2}$ Catalysts

\begin{tabular}{lccc}
\hline \multicolumn{1}{c}{ catalyst } & $\begin{array}{c}\text { surface area } \\
\left(\mathrm{m}^{2} / \mathrm{g}\right)\end{array}$ & $\begin{array}{c}\text { wt } \% \\
\mathrm{~V}_{2} \mathrm{O}_{5}{ }^{a}\end{array}$ & $\begin{array}{c}\text { surface density } \\
\left(\mathrm{V} \text { atom } / \mathrm{nm}^{2}\right)\end{array}$ \\
\hline $\mathrm{SiO}_{2}$ & 332 & 0.0 & 0.0 \\
$1 \% \mathrm{~V}_{2} \mathrm{O}_{5} / \mathrm{SiO}_{2}$ & 306 & 0.9 & 0.2 \\
$5 \% \mathrm{~V}_{2} \mathrm{O}_{5} / \mathrm{SiO}_{2}$ & 274 & 4.3 & 0.9 \\
$10 \% \mathrm{~V}_{2} \mathrm{O}_{5} / \mathrm{SiO}_{2}$ & 234 & 8.7 & 1.9 \\
$12 \% \mathrm{~V}_{2} \mathrm{O}_{5} / \mathrm{SiO}_{2}$ & 254 & 11.7 & 2.6 \\
$15 \% \mathrm{~V}_{2} \mathrm{O}_{5} / \mathrm{SiO}_{2}$ & 233 & 14.2 & 3.3 \\
${ }^{a}$ Actual $\mathrm{V}_{2} \mathrm{O}_{5}$ concentration obtained by atomic absorption.
\end{tabular}

the Kubelka-Munk function $F\left(R_{\infty}\right)$ from the absorbance. The band-gap energy $\left(E_{\mathrm{g}}\right)$ for allowed transitions was determined by finding the intercept of the straight line in the low-energy rise of a plot of $\left[F\left(R_{\infty}\right) \times h v\right]^{2}$ against $h v$, where $h v$ is the incident photon energy. ${ }^{22}$ Samples were loaded in a quartz flow cell with a Suprasil window. After each treatment, the quartz cell was quickly sealed off and cooled to room temperature for DRS measurements. The hydrated spectra were obtained under ambient conditions. The dehydrated spectra were obtained after samples were calcined at $500{ }^{\circ} \mathrm{C}$ in flowing $\mathrm{O}_{2} / \mathrm{He}$ for $1 \mathrm{~h}$. The DRS spectra for methanol chemisorption were recorded after the dehydrated samples were exposed to a gaseous mixture of $\mathrm{CH}_{3} \mathrm{OH} / \mathrm{O}_{2} / \mathrm{He}\left(4 \mathrm{~mol} \% \mathrm{CH}_{3} \mathrm{OH}\right.$ in the saturated gaseous mixture) at 120 or $230{ }^{\circ} \mathrm{C}$ for $30 \mathrm{~min}$.

4. X-ray Absorption Spectroscopy (XANES). The X-ray absorption experiments at the $\mathrm{V} \mathrm{K}$ edge were performed on beam line X19A at the National Synchrotron Light Source, Brookhaven National Laboratory. The storage ring operated at $2.5 \mathrm{GeV}$ with a current between 200 and $300 \mathrm{~mA}$. A quartz in situ XAFS cell with Kapton windows was used for XANES measurements. XANES spectra were initially acquired at room temperature in a He purge and after heating to $500{ }^{\circ} \mathrm{C}$ at 10 ${ }^{\circ} \mathrm{C} / \mathrm{min}$ in $\mathrm{O}_{2} / \mathrm{He}(20 / 80)$, holding for $30 \mathrm{~min}$ at $500{ }^{\circ} \mathrm{C}$, and then cooling to room temperature. The experimental details are described elsewhere. ${ }^{19}$

The XANES spectra were processed using the BAN software package. The energy scale for vanadium oxide was established by setting the first inflection point of the vanadium metal in the derivative spectrum at $5465.0 \mathrm{eV}$ to zero. The spectra were normalized to unity absorption by dividing by a least-squares fit of the absorption between 50 and $250 \mathrm{eV}$ above the absorption edge.

\section{Results}

1. Bulk Compositions and Surface Areas of the $\mathrm{V}_{2} \mathrm{O}_{5} /$ $\mathrm{SiO}_{2}$ Catalysts. The nominal and actual bulk compositions and surface areas of $\mathrm{V}_{2} \mathrm{O}_{5} / \mathrm{SiO}_{2}$ catalysts are presented in Table 1 . The actual $\mathrm{V}_{2} \mathrm{O}_{5}$ concentrations of the $\mathrm{V}_{2} \mathrm{O}_{5} / \mathrm{SiO}_{2}$ samples are only slightly in variance with the expected values. Unless otherwise notified, all vanadia loadings mentioned in the paper are referred to the nominal values. The surface area of the $\mathrm{V}_{2} \mathrm{O}_{5} /$ $\mathrm{SiO}_{2}$ samples decreases systematically with increasing vanadia loading.

2. Raman Spectroscopy. The Raman spectra of the dehydrated $0-15 \% \mathrm{~V}_{2} \mathrm{O}_{5} / \mathrm{SiO}_{2}$ samples are shown in Figure 1. The silica support possesses Raman features at $\sim 410, \sim 487$, 607,802 , and $\sim 976 \mathrm{~cm}^{-1}$. The $\sim 976 \mathrm{~cm}^{-1}$ band, which is associated with $\mathrm{Si}-\mathrm{OH}$ stretching mode of the surface hydroxyls, ${ }^{23}$ decreases with increasing vanadia loading. The bands at $\sim 802$ and $410-430 \mathrm{~cm}^{-1}$, which have been assigned to the symmetrical $\mathrm{Si}-\mathrm{O}-\mathrm{Si}$ stretching mode and the $\mathrm{Si}-\mathrm{O}-\mathrm{Si}$ bending mode, respectively, ${ }^{24}$ decrease with increasing vanadia

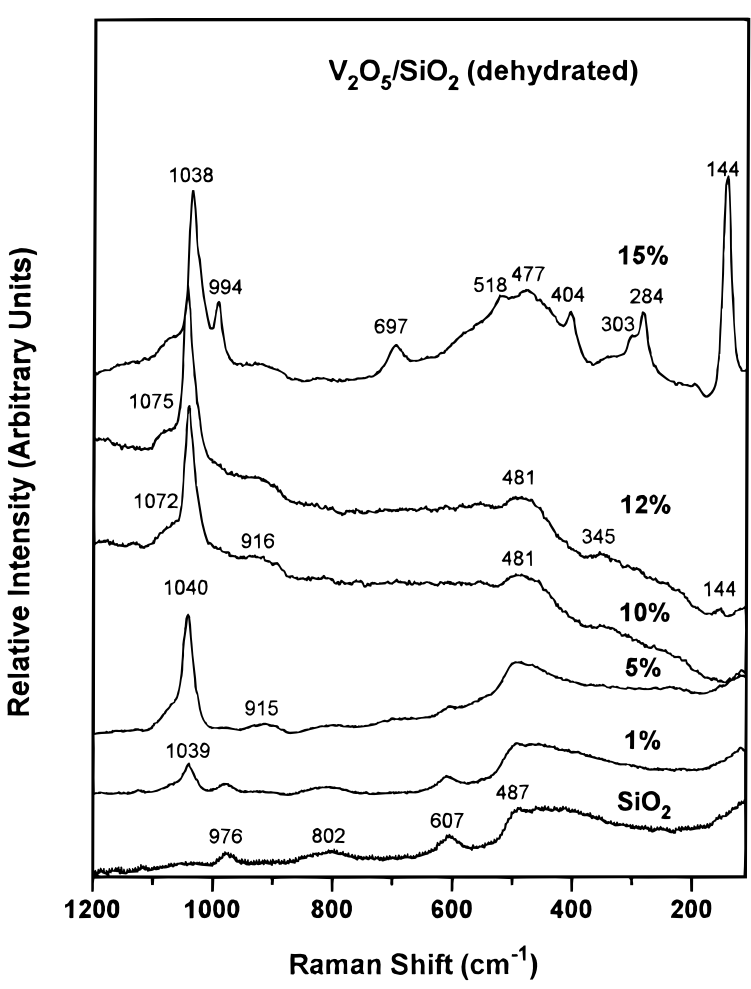

Figure 1. Raman spectra of the dehydrated $\mathrm{V}_{2} \mathrm{O}_{5} / \mathrm{SiO}_{2}$ samples.

loading, suggesting the breaking of $\mathrm{Si}-\mathrm{O}-\mathrm{Si}$ bridges. The broad bands at 607 and $487 \mathrm{~cm}^{-1}$ are assigned to D2 and D1 defect modes, which have been attributed to tri- and tetracyclosiloxane rings produced via the condensation of surface hydroxyls, respectively. ${ }^{20,24}$ A sharp band at $\sim 1040 \mathrm{~cm}^{-1}$ was observed for all the dehydrated $\mathrm{V}_{2} \mathrm{O}_{5} / \mathrm{SiO}_{2}$ samples, which has been assigned to the $\mathrm{V}=\mathrm{O}$ stretching vibration of isolated $\mathrm{VO}_{4}$ species. ${ }^{12,13}$ The Raman band at $607 \mathrm{~cm}^{-1}$ due to the threemembered rings of the silica support significantly decreases with increasing vanadia loading, suggesting that the number of threemember siloxane rings decreases upon dispersion of the surface vanadium oxide species. In addition, two broad Raman bands appear at $\sim 1075$ and $\sim 915 \mathrm{~cm}^{-1}$, and their intensity does not change noticeably with increasing vanadia loading. These two bands, which are also observed in the dehydrated, highly dispersed $\mathrm{TiO}_{2} / \mathrm{SiO}_{2}$ system, ${ }^{19}$ are characteristic of $\mathrm{Si}-\mathrm{O}^{-}$and $\mathrm{Si}\left(-\mathrm{O}^{-}\right)_{2}$ functionalities ${ }^{25}$ and can be assigned to perturbed silica vibrations that are indicative of the formation of $\mathrm{V}-\mathrm{O}-\mathrm{Si}$ bonds. These results reveal that in addition to the consumption of $\mathrm{Si}-\mathrm{OH}$ hydroxyls, the deposition of the surface vanadium oxide species also breaks some $\mathrm{Si}-\mathrm{O}-\mathrm{Si}$ siloxane bridges for the formation of $\mathrm{V}-\mathrm{O}-\mathrm{Si}$ bridging bonds. When the loading reaches $12 \% \mathrm{~V}_{2} \mathrm{O}_{5}$ on silica, a very weak Raman band appears at $\sim 144 \mathrm{~cm}^{-1}$, which is due to the formation of a trace amount of crystalline $\mathrm{V}_{2} \mathrm{O}_{5}$. This result demonstrates that the maximum coverage of surface vanadium oxide species on this $\mathrm{SiO}_{2}$ support is achieved at $\sim 2.6 \mathrm{~V}$ atoms $/ \mathrm{nm}^{2}$ (see Table 1). Even at this maximum coverage, no extra Raman bands, which might be related to $\mathrm{V}-\mathrm{O}-\mathrm{V}$ polymeric species, are observable. At $15 \%$ $\mathrm{V}_{2} \mathrm{O}_{5}$ loading, strong Raman bands due to $\mathrm{V}_{2} \mathrm{O}_{5}$ crystallites are shown at 994, 697, 518, 404, 303, 284, and $144 \mathrm{~cm}^{-1}$. However, the broad bands between 400 and $600 \mathrm{~cm}^{-1}$ seem much stronger than the combined bands due to both silica and crystalline $\mathrm{V}_{2} \mathrm{O}_{5}$ vibrations, which suggest the possible coexistence of an additional unknown vanadium oxide species.

The Raman spectra of the fully hydrated $1-12 \% \mathrm{~V}_{2} \mathrm{O}_{5} / \mathrm{SiO}_{2}$ samples are provided in Figure 2. These spectra are very similar 


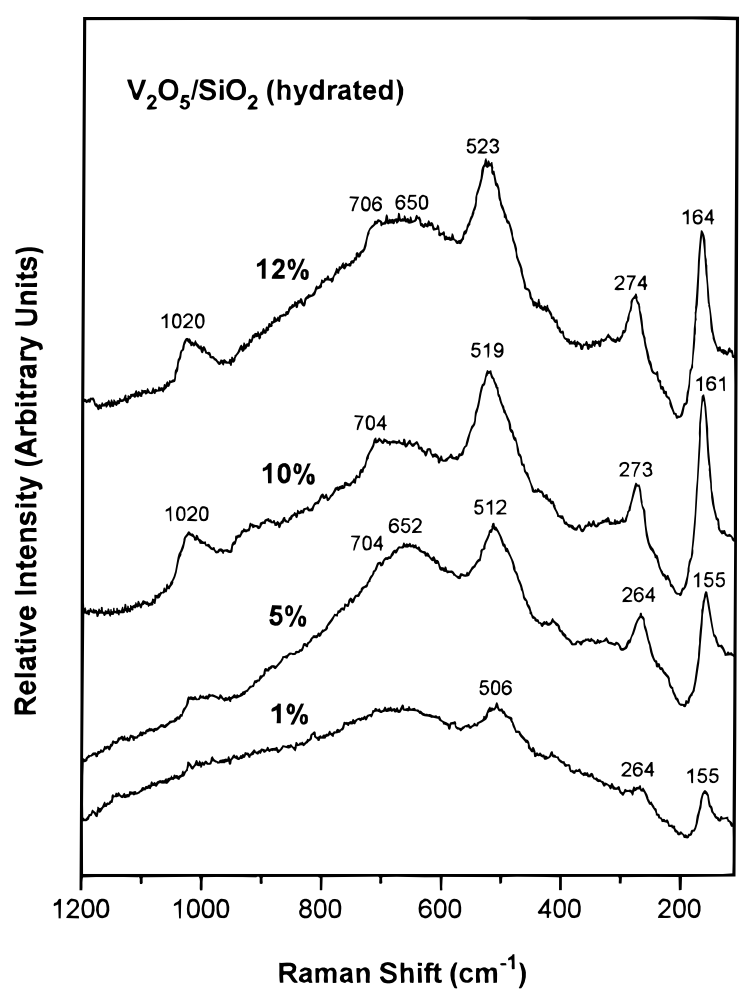

Figure 2. Raman spectra of the hydrated $\mathrm{V}_{2} \mathrm{O}_{5} / \mathrm{SiO}_{2}$ samples.

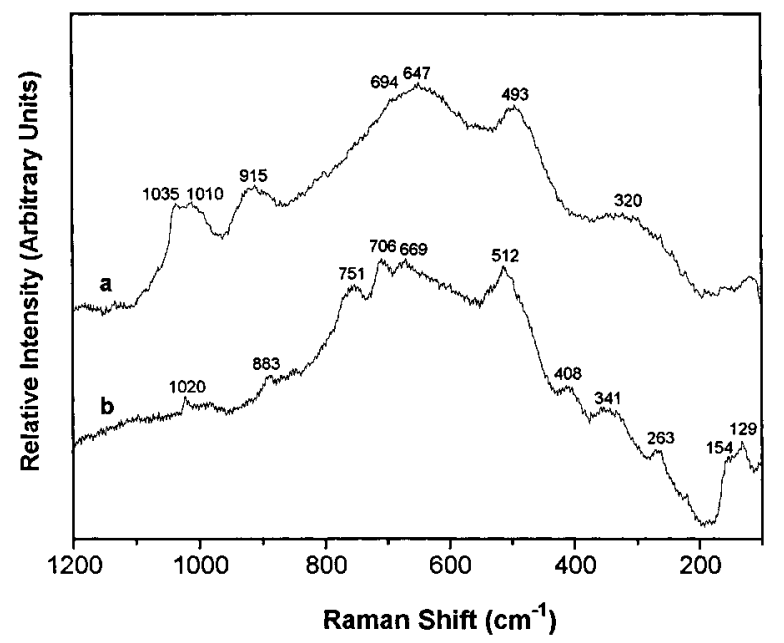

Figure 3. Raman spectra of (a) the partially hydrated $10 \% \mathrm{~V}_{2} \mathrm{O}_{5} / \mathrm{SiO}_{2}$ sample and (b) the aqueous $\mathrm{VO}_{x}$ species extracted from $\mathrm{V}_{2} \mathrm{O}_{5} / \mathrm{SiO}_{2}$.

regardless of the vanadia loading. Five broad bands are observed at $\sim 1020, \sim 704, \sim 652,506-523,264-274$, and $155-164 \mathrm{~cm}^{-1}$. These bands have been simply assigned to hydrated amorphous $\mathrm{V}_{2} \mathrm{O}_{5}$-like species because of their similarity to the Raman bands of $\mathrm{V}_{2} \mathrm{O}_{5}$ crystallites. ${ }^{12}$ It is interesting to note that as the loading increases from $1 \%$ to $12 \% \mathrm{~V}_{2} \mathrm{O}_{5}$, the last three bands blue shift from 506 to 523, 264 to 274, and 155 to $164 \mathrm{~cm}^{-1}$. These blue shifts may be related to the shortening of some $\mathrm{V}-\mathrm{O}$ bond lengths with increasing vanadia concentration on the silica surface since the $\mathrm{V}-\mathrm{O}$ bond length is inversely correlated with the Raman vibrational frequency as established by Hardcastle and Wachs. ${ }^{26}$

The Raman spectrum of the partially hydrated $10 \% \quad \mathrm{~V}_{2} \mathrm{O}_{5} /$ $\mathrm{SiO}_{2}$ sample that was slightly exposed to moisture for a short time is shown in Figure 3a. Partial hydration of the dehydrated sample changes the sample color from white to light yellow, and the sample becomes deep red when fully hydrated. For
TABLE 2: Comparison of Raman Frequencies of $\mathrm{VO}_{x}-\mathrm{H}_{2} \mathrm{O}$-Containing Samples

\begin{tabular}{cc}
\hline sample & Raman bands $\left(\mathrm{cm}^{-1}\right)$ \\
\hline $10 \% \mathrm{~V}_{2} \mathrm{O}_{5} / \mathrm{SiO}_{2}$ & $1020,704,652,519,273,161$ \\
(fully hydrated) & \\
${\text { aqueous } \mathrm{VO}_{x} \text { species }}^{a}$ & $1020,883,751,706,669,512,408,341,263$, \\
& 154,129 \\
$\mathrm{~V}_{2} \mathrm{O}_{5} \cdot 1.2 \mathrm{H}_{2} \mathrm{O}^{b}$ & $1020,895,707,668,510,485,400,350,325$, \\
(xerogel powder) & $278,265,156,135$ \\
$\mathrm{~V}_{2} \mathrm{O}_{5}$ crystallites & $994,697,518,477,404,303,284,144$
\end{tabular}

${ }^{a}$ Aqueous $\mathrm{VO}_{x}$ species extracted from the $9 \% \mathrm{~V}_{2} \mathrm{O}_{5} / \mathrm{SiO}_{2}$ sample. ${ }^{b}$ Obtained from ref 27.

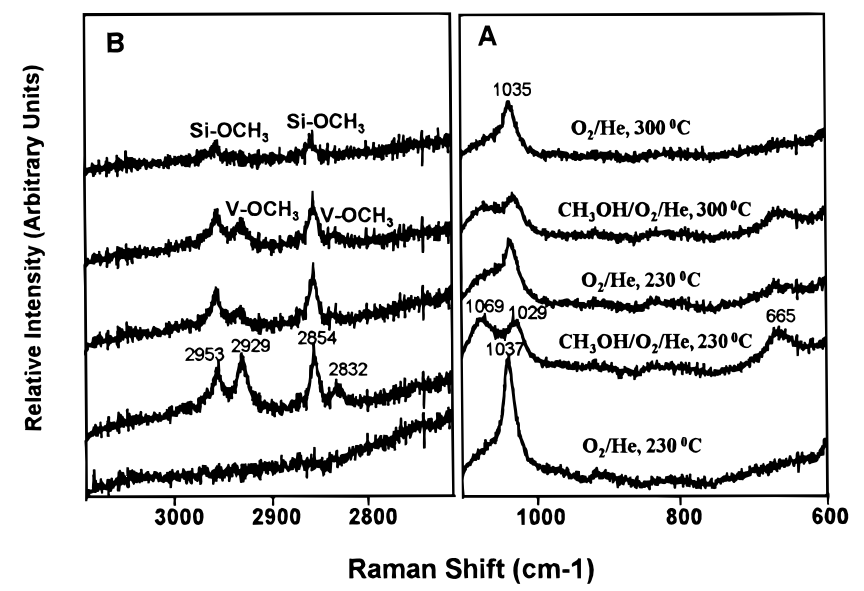

Figure 4. In situ Raman spectra of the $5 \% \mathrm{~V}_{2} \mathrm{O}_{5} / \mathrm{SiO}_{2}$ sample during methanol oxidation.

this partially hydrated sample, broad Raman bands are observed at $1035-1010,915,694,647,493$, and $\sim 320 \mathrm{~cm}^{-1}$, which are very different from the bands observed for the fully hydrated and dehydrated samples. These results indicate that the molecular structure of surface vanadium oxide species on silica is dependent on the degree of hydration.

To fully understand the hydration effect on the molecular structure of the $\mathrm{V}_{2} \mathrm{O}_{5} / \mathrm{SiO}_{2}$ catalysts, liquid water was added to the $9 \% \quad \mathrm{~V}_{2} \mathrm{O}_{5} / \mathrm{SiO}_{2}$ sample. It was found that the surface vanadium oxide species are extractable from the silica surface, resulting in a deep red transparent solution and a $\mathrm{SiO}_{2}$ solid with $\sim 0.6 \% \quad \mathrm{~V}_{2} \mathrm{O}_{5}$ remaining on the surface. Once the $\mathrm{VO}_{x}$ species leave the surface to the solution, they cannot be redispersed as surface species onto the silica surface again since the calcination of the mixture of the red transparent solution and the silica support only results in $\mathrm{V}_{2} \mathrm{O}_{5}$ crystallites. The Raman spectrum of this deep red solution is provided in Figure $3 \mathrm{~b}$, which is similar, but not identical, to the Raman spectra of the fully hydrated $\mathrm{V}_{2} \mathrm{O}_{5} / \mathrm{SiO}_{2}$ samples shown in Figure 2 (also see Table 2). In addition, it is noted that concentrating or diluting of the solution changes its Raman spectrum. Interestingly, the best match of the Raman spectra of the aqueous $\mathrm{VO}_{x}$ species extracted from the $\mathrm{V}_{2} \mathrm{O}_{5} / \mathrm{SiO}_{2}$ sample is the Raman spectra of $\mathrm{V}_{2} \mathrm{O}_{5} \cdot n \mathrm{H}_{2} \mathrm{O}$ xerogel ${ }^{27}$ (see Table 2). Some spectral differences, such as the broadening of Raman bands for the aqueous $\mathrm{VO}_{x}$ species, may be expected because of their different physical states. Therefore, the molecular structure of the fully hydrated surface vanadium oxide species on silica closely resembles $\mathrm{V}_{2} \mathrm{O}_{5} \cdot n \mathrm{H}_{2} \mathrm{O}$ gels, rather than $\mathrm{V}_{2} \mathrm{O}_{5}$ crystallites.

The in situ Raman spectra of the $5 \% \quad \mathrm{~V}_{2} \mathrm{O}_{5} / \mathrm{SiO}_{2}$ sample during methanol oxidation are presented in Figure 4 . In the C-H vibration region, Raman bands at $\sim 2953, \sim 2930,2854$, and $2832 \mathrm{~cm}^{-1}$, due to methanol chemisorption, are observed when methanol is introduced in the feed stream. The bands at 


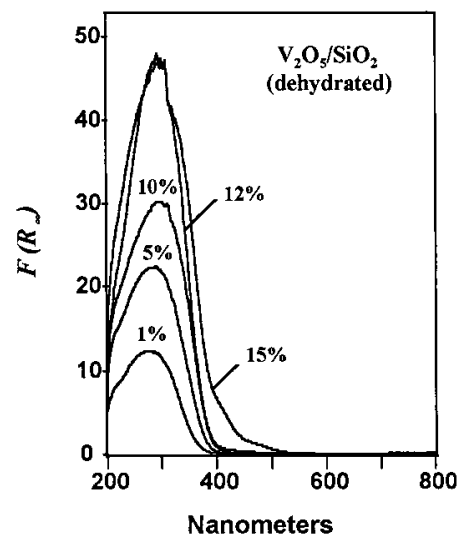

Figure 5. UV-vis DRS spectra of the dehydrated $\mathrm{V}_{2} \mathrm{O}_{5} / \mathrm{SiO}_{2}$ samples.

$\sim 2953$ and $\sim 2854 \mathrm{~cm}^{-1}$ are characteristic of the $\mathrm{C}-\mathrm{H}$ stretching vibrations of the surface methoxy species on the silica support $\left(\mathrm{Si}-\mathrm{OCH}_{3}\right),{ }^{21}$ whereas the Raman bands at $\sim 2930$ and $\sim 2832$ $\mathrm{cm}^{-1}$ are assigned to the $\mathrm{C}-\mathrm{H}$ stretching vibrations of the surface V-methoxy groups. ${ }^{21}$ The surface V-methoxy species on $\mathrm{SiO}_{2}$ are less stable than the $\mathrm{Si}$-methoxy species because the Raman band intensity of the V-methoxy species decreases substantially relative to the $\mathrm{Si}$-methoxy species when methanol is removed from the feed stream, as shown in Figure 4B.

In the lower wavenumber region (Figure 4A), three Raman bands at $\sim 1069, \sim 1029$, and $665 \mathrm{~cm}^{-1}$ are observed when methanol is introduced. The assignment of these bands needs to be careful because both $\mathrm{C}-\mathrm{O}$ and $\mathrm{V}=\mathrm{O}$ stretching vibrations may occur in $1000-1080 \mathrm{~cm}^{-1}$ region. During methanol oxidation, the change of one of the $\mathrm{Si}(\mathrm{IV})-\mathrm{O}^{-}$ligands around the $\mathrm{V}$ cation by $\mathrm{CH}_{3} \mathrm{O}^{-}$may change the $\mathrm{V}=\mathrm{O}$ stretching frequency. For example, the Raman $\mathrm{V}=\mathrm{O}$ stretching frequency of the monomeric $\left(\mathrm{CH}_{3} \mathrm{O}\right)_{2} \mathrm{VO}_{2}{ }^{-}$complex is observed at 926 $\mathrm{cm}^{-1}$, while the $\mathrm{V}=\mathrm{O}$ stretching frequency of the monomeric $(\mathrm{HO})_{2} \mathrm{VO}_{2}{ }^{-}$is $9 \mathrm{~cm}^{-1}$ higher. ${ }^{28}$ In addition, the $\mathrm{V}=\mathrm{O}$ stretching frequency of the $\left[\left(\mathrm{ClCH}_{2} \mathrm{CH}_{2} \mathrm{O}\right)_{3} \mathrm{VO}\right]_{2}$ compound appears at $1007 \mathrm{~cm}^{-1} .^{28}$ Therefore, the formation of surface V-methoxy species on silica may result in a modest red shift of the $\mathrm{V}=\mathrm{O}$ stretching frequency since the electronegativity of $\mathrm{CH}_{3} \mathrm{O}^{-}$is expected to be relatively lower than that of $\mathrm{Si}(\mathrm{IV})-\mathrm{O}^{-},{ }^{29}$ which suggests that the $1029 \mathrm{~cm}^{-1}$ band may be assigned to the $\mathrm{V}=\mathrm{O}$ stretching vibration of the surface $\mathrm{V}$-methoxy species. The possible effect of water on the $\mathrm{V}=\mathrm{O}$ vibration can be excluded since no spectral change was observed at $230{ }^{\circ} \mathrm{C}$ even in the presence of water vapor. ${ }^{30}$ Furthermore, it has been reported that the $\mathrm{C}-\mathrm{O}$ and $\mathrm{M}-\mathrm{O}$ stretching vibrations of some group IVB and VB metal ethoxides occur at $1029-1072 \mathrm{~cm}^{-1}$ and $550-625 \mathrm{~cm}^{-1}$, respectively. ${ }^{31}$ It is reasonable to assume that the Raman bands at $\sim 1069$ and $665 \mathrm{~cm}^{-1}$ are associated with the $\mathrm{C}-\mathrm{O}$ and $\mathrm{V}-\mathrm{O}$ stretching vibrations of the surface $\mathrm{V}$-methoxy species, respectively. The Raman results suggest that most of the $\mathrm{V}$ sites are involved in methanol chemisorption during the oxidation reaction.

3. UV-Vis-NIR Diffuse Reflectance Spectroscopy. The UV-vis DRS spectra of the dehydrated $1 \%-15 \% \quad \mathrm{~V}_{2} \mathrm{O}_{5} / \mathrm{SiO}_{2}$ samples are presented in Figure 5, and their band maxima and edge energies are summarized in Table 3. No absorption was observed on pure silica. ${ }^{19}$ For the $1 \%-12 \% \mathrm{~V}_{2} \mathrm{O}_{5} / \mathrm{SiO}_{2}$ samples, only one LMCT band is observed, indicating that the vanadium oxide species are well dispersed in these samples. The band maximum red shifts from 278 to $298 \mathrm{~nm}$ and the corresponding edge energy has a minor shift from 3.6 to $3.4 \mathrm{eV}$ as the loading increases from $1 \%$ to $12 \% \mathrm{~V}_{2} \mathrm{O}_{5}$. At the $15 \% \mathrm{~V}_{2} \mathrm{O}_{5}$ loading, two weak shoulders appear at $\sim 410$ and $481 \mathrm{~nm}$. The $481 \mathrm{~nm}$
TABLE 3: Band Maxima and Edge Energies of Hydrated and Dehydrated $\mathrm{V}_{2} \mathrm{O}_{5} / \mathrm{SiO}_{2}$ Catalysts

\begin{tabular}{llclc}
\hline \multicolumn{1}{c}{ catalysts } & $\begin{array}{c}\text { band max. } \\
(\mathrm{nm})(\text { dehy.) }\end{array}$ & $\begin{array}{c}E_{\mathrm{g}}(\mathrm{eV}) \\
\text { (dehydrated) }\end{array}$ & $\begin{array}{c}\text { band max. } \\
(\mathrm{nm})(\text { hydr. })\end{array}$ & $\begin{array}{c}E_{\mathrm{g}}(\mathrm{eV}) \\
\text { (hydr.) }\end{array}$ \\
\hline $1 \% \mathrm{~V}_{2} \mathrm{O}_{5} / \mathrm{SiO}_{2}$ & 278 & 3.6 & 283,426 & 2.5 \\
$5 \% \mathrm{~V}_{2} \mathrm{O}_{5} / \mathrm{SiO}_{2}$ & 286 & 3.5 & 285,433 & 2.4 \\
$10 \% \mathrm{~V}_{2} \mathrm{O}_{5} / \mathrm{SiO}_{2}$ & 298 & 3.4 & 278,436 & 2.4 \\
$12 \% \mathrm{~V}_{2} \mathrm{O}_{5} / \mathrm{SiO}_{2}$ & 298 & 3.4 & 282,417 & 2.5 \\
$15 \% \mathrm{~V}_{2} \mathrm{O}_{5} / \mathrm{SiO}_{2}$ & $298,410(\mathrm{sh})$, & 3.3 & $280-440$ & 2.4 \\
& $481(\mathrm{sh})$ & & &
\end{tabular}

TABLE 4: Band Maxima and Edge Energies of V-Reference Compounds

\begin{tabular}{|c|c|c|c|}
\hline compounds & $\begin{array}{l}\text { band max. } \\
\qquad(\mathrm{nm})\end{array}$ & $\begin{array}{c}E_{\mathrm{g}} \\
(\mathrm{eV})\end{array}$ & molecular structure ${ }^{a}$ \\
\hline $\mathrm{V}_{2} \mathrm{O}_{5}$ & $236,334,481$ & 2.3 & polymerized $\mathrm{VO}_{5} / \mathrm{VO}_{6}$ \\
\hline $\begin{array}{l}\mathrm{MgV}_{2} \mathrm{O}_{6} \\
\text { (meta-vanadate) }\end{array}$ & 250,370 & 2.8 & polymerized $\mathrm{VO}_{6}$ \\
\hline $\begin{array}{l}\mathrm{NaVO}_{3} \\
\quad \text { (meta-vanadate) }\end{array}$ & 281,353 & 3.2 & polymerized $\mathrm{VO}_{4}$ \\
\hline $\begin{array}{l}\mathrm{NH}_{4} \mathrm{VO}_{3} \\
\quad \text { (meta-vanadate) }\end{array}$ & 288,363 & 3.2 & polymerized $\mathrm{VO}_{4}$ \\
\hline $\begin{array}{l}\mathrm{Mg}_{2} \mathrm{~V}_{2} \mathrm{O}_{7} \\
\quad \text { (pyro-vanadate) }\end{array}$ & 280 & 3.5 & dimeric $\mathrm{VO}_{4}$ \\
\hline $\begin{array}{l}\mathrm{Mg}_{3} \mathrm{~V}_{2} \mathrm{O}_{8} \\
\quad \text { (ortho-vanadate) }\end{array}$ & 260,303 & 3.5 & isolated $\mathrm{VO}_{4}$ \\
\hline $\begin{array}{l}\mathrm{Na}_{3} \mathrm{VO}_{4} \\
\quad \text { (ortho-vanadate) }\end{array}$ & 253,294 & 3.9 & isolated $\mathrm{VO}_{4}$ \\
\hline
\end{tabular}

${ }^{a}$ Molecular structures are assigned from references listed below: $\mathrm{V}_{2} \mathrm{O}_{5}$, ref 32 (the molecular structure of $\mathrm{V}_{2} \mathrm{O}_{5}$ consists of distorted tetragonal pyramids sharing edges and corners to form layers, which can be regarded as polymerized $\mathrm{VO}_{5}$ units. However, each nonbridging oxygen acts as a sixth neighbor to a $\mathrm{V}$ atom in an adjacent layer, which can also be considered as a highly distorted $\mathrm{VO}_{6}$ configuration). $\mathrm{NaVO}_{3}$, ref 33. $\mathrm{NH}_{4} \mathrm{VO}_{3}$, ref 34. $\mathrm{Na}_{3} \mathrm{VO}_{4}$, ref 35. $\mathrm{MgV}_{2} \mathrm{O}_{6}$, refs 36, 37. $\mathrm{Mg}_{2} \mathrm{~V}_{2} \mathrm{O}_{7}$, refs 37, 38 (the molecular structure of $\mathrm{Mg}_{2} \mathrm{~V}_{2} \mathrm{O}_{7}$ consists of chains of edge sharing $\mathrm{V}_{2} \mathrm{O}_{7}$ groups. These $\mathrm{V}_{2} \mathrm{O}_{7}$ groups are composed of cornersharing $\mathrm{VO}_{4}$ tetrahedra, with a weak fifth $\mathrm{V}-\mathrm{O}$ bond at either end. The vanadium cations are thus considered as 5-fold coordinated. However, ${ }^{51} \mathrm{~V}$ NMR spectra of $\mathrm{Mg}_{2} \mathrm{~V}_{2} \mathrm{O}_{7}{ }^{37 \mathrm{a}}$ show two $\mathrm{V}$ sites with tetrahedral environments: one is very similar to that of $\mathrm{Mg}_{3} \mathrm{~V}_{2} \mathrm{O}_{8}$, the other is a distorted $\mathrm{VO}_{4}$ structure. The results suggest that the molecular structure of $\mathrm{Mg}_{2} \mathrm{~V}_{2} \mathrm{O}_{7}$ is better represented by dimeric $\left.\mathrm{VO}_{4}\right) . \mathrm{Mg}_{3} \mathrm{~V}_{2} \mathrm{O}_{8}$, refs 37,39
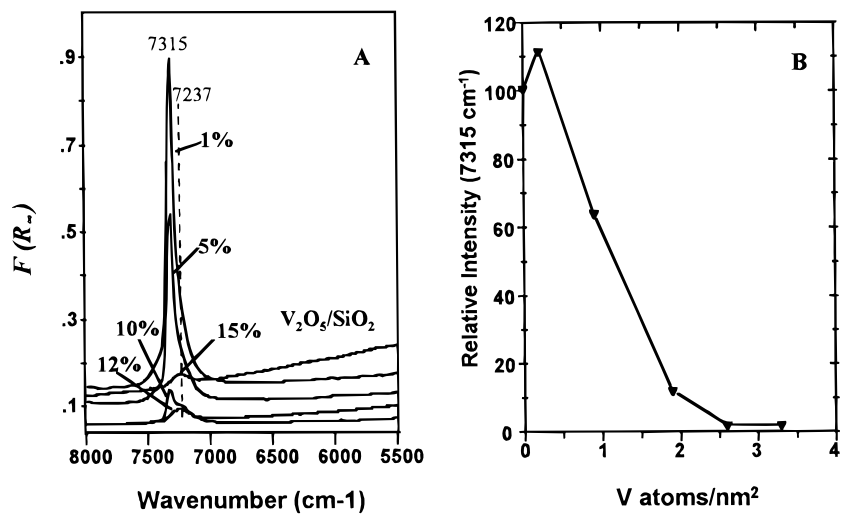

Figure 6. (A) NIR DRS spectra of the dehydrated $\mathrm{V}_{2} \mathrm{O}_{5} / \mathrm{SiO}_{2}$ samples; (B) the relative intensity of isolated surface $\mathrm{Si}-\mathrm{OH}$ hydroxyls (7315 $\mathrm{cm}^{-1}$ ) as a function of $\mathrm{V}$ surface density.

band is due to the formation of a small amount of $\mathrm{V}_{2} \mathrm{O}_{5}$ crystallites that exhibit LMCT bands at 236, 334, and $481 \mathrm{~nm}$ (see Table 4). However, the $410 \mathrm{~nm}$ band is unknown and may be associated with the vanadium oxide species unidentified by Raman spectroscopy.

In the corresponding NIR region (Figure 6A), where the overtone and combination bands of hydroxyls are located, the 


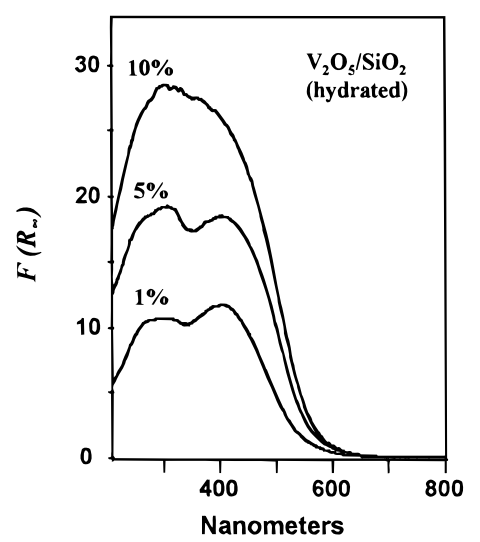

Figure 7. UV-vis DRS spectra of the hydrated $\mathrm{V}_{2} \mathrm{O}_{5} / \mathrm{SiO}_{2}$ samples.

$7315 \mathrm{~cm}^{-1}$ band due to the surface isolated $\mathrm{Si}-\mathrm{OH}$ groups decreases substantially with increasing vanadia loading and disappears at loadings of $12 \% \mathrm{~V}_{2} \mathrm{O}_{5}$ and above. A band at 7245 $\mathrm{cm}^{-1}$, which may previously be overlapped by the strong 7315 $\mathrm{cm}^{-1}$ band, shows up and does not change noticeably up to the $15 \% \mathrm{~V}_{2} \mathrm{O}_{5}$ loading. The amount of the isolated $\mathrm{Si}-\mathrm{OH}$ hydroxyls relative to the pure $\mathrm{SiO}_{2}$ support is plotted as a function of the $\mathrm{V}$ surface density in Figure $6 \mathrm{~B}$. As the vanadia loading increases from $1 \%$ to $12 \% \mathrm{~V}_{2} \mathrm{O}_{5}$, the sharp decrease in the relative amount of the isolated $\mathrm{Si}-\mathrm{OH}$ hydroxyls demonstrates that deposition of the surface vanadium oxide species significantly consumes the surface $\mathrm{Si}-\mathrm{OH}$ hydroxyls and the maximum surface coverage of vanadium oxide is achieved at around $12 \% \mathrm{~V}_{2} \mathrm{O}_{5}$, which is consistent with Raman results. The hydroxyls contributing to the absorption at $7245 \mathrm{~cm}^{-1}$ might be the remaining inaccessible $\mathrm{Si}-\mathrm{OH}$ hydroxyls. Among these hydroxyls, only a small percentage can be exchanged by deuterium through $\mathrm{D}_{2} \mathrm{O}$ adsorption experiments $(<30 \%)$, suggesting that these hydroxyls are mainly inaccessible $\mathrm{Si}-\mathrm{OH}$ hydroxyls.

The UV-vis DRS spectra of the hydrated $1 \%-10 \% \mathrm{~V}_{2} \mathrm{O}_{5} /$ $\mathrm{SiO}_{2}$ samples are shown in Figure 7, and the band maxima and edge energies are listed in Table 3. Two LMCT bands centered at around $278-285$ and $417-436 \mathrm{~nm}$ are observed for $1 \%$ $-12 \% \mathrm{~V}_{2} \mathrm{O}_{5} / \mathrm{SiO}_{2}$ samples. Higher loading samples $(\geq 10 \%$ $\mathrm{V}_{2} \mathrm{O}_{5}$ ) usually exhibit ill-defined bands. Ray and Post ${ }^{28}$ reported that $\mathrm{VO}_{4}$ monomers in various solvents absorb at $\sim 270 \mathrm{~nm}$, while $\mathrm{VO}_{6}$ complex monomers absorb at $\sim 300 \mathrm{~nm}$. Thus, the presence of absorption at $410-440 \mathrm{~nm}$ suggests that the fully hydrated surface vanadium oxide species on $\mathrm{SiO}_{2}$ must be polymerized $\mathrm{VO}_{x}$ species. The edge energy of the hydrated $1 \%-15 \% \mathrm{~V}_{2} \mathrm{O}_{5} / \mathrm{SiO}_{2}$ samples is $\sim 1 \mathrm{eV}$ lower than the corresponding edge energy of the dehydrated samples and is almost identical regardless of vanadia loading $(2.4-2.5 \mathrm{eV}$, see Table $3)$. The results suggest that the molecular structure of the hydrated surface vanadium oxide species on silica is very similar regardless of vanadia loading, in agreement with the Raman results.

To better understand the effect of the coordination geometry and ligands on the LMCT band maximum and edge energy of the central $\mathrm{V}(\mathrm{V})$ cations, some $\mathrm{V}(\mathrm{V})$ compounds with welldefined structures were used as references for the UV-vis DRS spectral analysis. Their band maxima, edge energies, and molecular structural assignments are presented in Table 4. The number, maximum position, and relative intensity of the LMCT bands are determined by the number and type of ligands, molecular structure, and transitions between different molecular orbitals. No general rule could easily be deduced from these parameters. However, comparison of the edge energy of LMCT transitions in association with the different molecular structures of V-reference compounds appears very informative. The edge energy, or in other words the band-gap energy of $\mathrm{V}_{2} \mathrm{O}_{5}$ crystallites, is $2.3 \mathrm{eV}$ in this work, in good agreement with the literature value of $2.3-2.4 \mathrm{eV} .{ }^{40-42}$ From the results in Table 4 , it is concluded that three major factors affect the edge energy of the $\mathrm{V}(\mathrm{V})$ cations, as discussed below:

(i) Polymerization of the $\mathrm{V}$ cations. The polymerization of $\mathrm{VO}_{6}$ or $\mathrm{VO}_{4}$ units tends to lower the edge energy, and the polymerized $\mathrm{VO}_{6}$ structures exhibit the lowest edge energy. The lowest edge energy of $2.3 \mathrm{eV}$ is observed for $\mathrm{V}_{2} \mathrm{O}_{5}$ crystallites that consist of polymerized, highly distorted $\mathrm{VO}_{6}$ units, and compounds composed of isolated $\mathrm{VO}_{4}$ units exhibit the highest edge energy. For $\mathrm{Na}^{+}$cations, the edge energy of metavanadate $\left(\mathrm{NaVO}_{3}\right)$ with polymerized $\mathrm{VO}_{4}$ units is $0.7 \mathrm{eV}$ lower than that of orthovanadate $\left(\mathrm{Na}_{3} \mathrm{VO}_{4}\right)$ with isolated $\mathrm{VO}_{4}$ units.

(ii) Changes in coordination geometry. The edge energy of $\mathrm{Na}$-metavanadate $\left(\mathrm{NaVO}_{3}\right)$ with polymerized $\mathrm{VO}_{4}$ units possesses a higher value than that of $\mathrm{Mg}$-metavanadate $\left(\mathrm{MgV}_{2} \mathrm{O}_{6}\right)$ with polymerized $\mathrm{VO}_{6}$ units, indicating that an increase in coordination number may increase the edge energy. However, a change in edge energy due to a coordination change is also often accompanied by a change in the second coordination sphere, i.e., the ligands of the central V(V) cations. In addition, structural distortion from perfect tetrahedra or octahedra may also result in some changes in the edge energy.

(iii) Changes in the second coordination sphere around $\mathrm{V}(\mathrm{V})$ cations. The edge energy of $\mathrm{Mg}$-orthovanadate $\left(\mathrm{Mg}_{3} \mathrm{~V}_{2} \mathrm{O}_{8}\right)$ is $0.4 \mathrm{eV}$ less than that of Na-orthovanadate $\left(\mathrm{Na}_{3} \mathrm{VO}_{4}\right)$, indicating that the change in cations in the second coordination sphere around the $\mathrm{VO}_{4}$ unit may significantly affect the edge energy since both compounds possess the isolated $\mathrm{VO}_{4}$ structure. Also, Mg-metavanadate $\left(\mathrm{MgV}_{2} \mathrm{O}_{6}\right)$ consists of polymerized $\mathrm{VO}_{6}$ units similar to those present in $\mathrm{V}_{2} \mathrm{O}_{5}$ crystallites; the presence of $\mathrm{Mg}^{2+}$ cations as the second coordination sphere of the $\mathrm{V}$ cations may partly contribute to the increase of the edge energy by 0.5 $\mathrm{eV}$ compared to crystalline $\mathrm{V}_{2} \mathrm{O}_{5}$. The structural change, e.g., the lowering of symmetry $T_{d} \rightarrow C_{3 v} \rightarrow C_{s}$, may also affect the edge position of the $\mathrm{V}(\mathrm{V})$ cations.

The information obtained from the V-reference compounds enables us to more accurately assign the molecular structures of the surface vanadium oxide species on silica under both hydrated and dehydrated conditions. The hydrated $1 \%-15 \%$ $\mathrm{V}_{2} \mathrm{O}_{5} / \mathrm{SiO}_{2}$ samples possess essentially the same edge energy of $2.4-2.5 \mathrm{eV}$, suggesting that the molecular structure of the hydrated vanadium oxide species on the silica support is very similar regardless of the vanadia loading. In addition, these edge energy values are very close to that of $\mathrm{V}_{2} \mathrm{O}_{5}$ crystallites $(2.3 \mathrm{eV})$, which is usually associated with the LMCT transition from a mainly oxygen $2 \mathrm{p}$ to vanadium $3 \mathrm{~d}$ band. ${ }^{40,41}$ This result suggests that the hydrated vanadium oxide species are highly polymerized $\mathrm{VO}_{5} / \mathrm{VO}_{6}$ species. Dehydration substantially increases the edge energies of these samples. For the dehydrated $1 \%-12 \% \mathrm{~V}_{2} \mathrm{O}_{5} / \mathrm{SiO}_{2}$ samples, the edge energies fall in a narrow range of 3.4-3.6 eV, suggesting that the molecular structure of the dehydrated surface vanadium oxide species is also very similar regardless of the vanadia loading. These high values of edge energy are consistent with an isolated $\mathrm{VO}_{4}$ structure. However, some variances are expected since the symmetry and ligands around $\mathrm{V}(\mathrm{V})$ cations on the silica surface are not the same as the $\mathrm{V}$-reference compounds. For the dehydrated $15 \%$ $\mathrm{V}_{2} \mathrm{O}_{5} / \mathrm{SiO}_{2}$ sample, the presence of a small amount of $\mathrm{V}_{2} \mathrm{O}_{5}$ crystallites may be responsible for the slightly lower edge energy of $3.3 \mathrm{eV}$. 


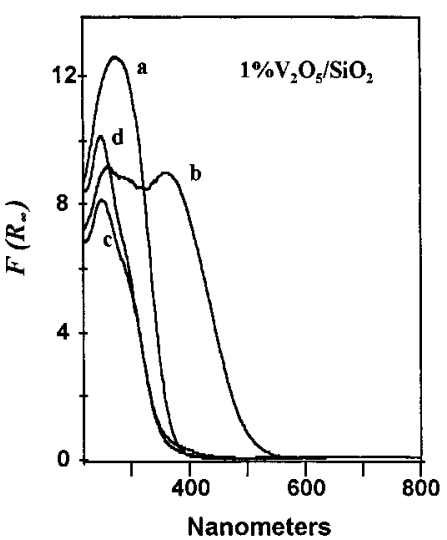

Figure 8. UV-vis DRS spectra of the $1 \% \mathrm{~V}_{2} \mathrm{O}_{5} / \mathrm{SiO}_{2}$ sample after (a) $\mathrm{O}_{2} / \mathrm{He}, 500{ }^{\circ} \mathrm{C}$; (b) $\mathrm{CH}_{3} \mathrm{OH} / \mathrm{O}_{2} / \mathrm{He}$, r.t.; (c) $\mathrm{CH}_{3} \mathrm{OH} / \mathrm{O}_{2} / \mathrm{He}, 120{ }^{\circ} \mathrm{C}$; (d) $\mathrm{CH}_{3} \mathrm{OH} / \mathrm{O}_{2} / \mathrm{He}, 230{ }^{\circ} \mathrm{C}$.

TABLE 5: Band Maxima and Edge Energies of $1 \%$ $\mathrm{V}_{2} \mathrm{O}_{5} / \mathrm{SiO}_{2}$ after Methanol Adsorption at Various Temperatures

\begin{tabular}{llc}
\hline \multicolumn{1}{c}{ conditions } & band max. $(\mathrm{nm})$ & $E_{\mathrm{g}}(\mathrm{eV})$ \\
\hline $\mathrm{MeOH} / \mathrm{O}_{2} / \mathrm{He}$, r.t. & 265,370 & 2.7 \\
$\mathrm{MeOH} / \mathrm{O}_{2} / \mathrm{He}, 120^{\circ} \mathrm{C}$ & $252,310(\mathrm{sh})$ & 3.7 \\
$\mathrm{MeOH} / \mathrm{O}_{2} / \mathrm{He}, 230^{\circ} \mathrm{C}$ & $249,306(\mathrm{sh})$ & 3.8
\end{tabular}

The UV-vis DRS spectra of the $1 \% \quad \mathrm{~V}_{2} \mathrm{O}_{5} / \mathrm{SiO}_{2}$ sample during methanol oxidation at various temperatures are shown in Figure 8, and the corresponding edge energies are provided in Table 5. Two LMCT bands at 265 and $370 \mathrm{~nm}$ are observed after methanol adsorption at room temperature with an edge energy of $2.7 \mathrm{eV}$, suggesting that the surface vanadium oxide species saturated with methanol are highly polymerized $\mathrm{VO}_{6}$ species, similar to the fully hydrated vanadium oxide species. Increasing the temperature dramatically changes the spectral feature as well as the edge energy. At $120{ }^{\circ} \mathrm{C}$, the LMCT transitions appear at 252 and 310 (shoulder) $\mathrm{nm}$ and the edge energy increases to $3.7 \mathrm{eV}$. A higher temperature of $230{ }^{\circ} \mathrm{C}$ even increases the edge energy further to $3.8 \mathrm{eV}$. As discussed above for the $\mathrm{V}(\mathrm{V})$-reference compounds, the ligand change as well as the structural symmetry change may change the edge energy of the central $\mathrm{V}(\mathrm{V})$ cations. Nevertheless, these high values of edge energy $(3.7-3.8 \mathrm{eV})$ strongly suggest that the $\mathrm{V}(\mathrm{V})$ cations on silica after methanol chemisorption at high temperatures $\left(>100{ }^{\circ} \mathrm{C}\right)$ are isolated $\mathrm{VO}_{4}$ species. The significantly lower band intensity indicates that the absorption coefficient of the 4-fold coordinated V-methoxy species is much lower than that of the 4-fold coordinated surface vanadium oxide species.

In the corresponding NIR region shown in Figure 9, methanol chemisorption at $120{ }^{\circ} \mathrm{C}$ dramatically decreases the $7315 \mathrm{~cm}^{-1}$ band owing to isolated $\mathrm{Si}-\mathrm{OH}$ hydroxyls. A much less intense band appears at $7231 \mathrm{~cm}^{-1}$, together with a new, broad band at $5898 \mathrm{~cm}^{-1}$ due to the $2 v$ overtone vibrations of surface $\mathrm{V}$ - and Si-methoxy species since both species are also detected by in situ Raman experiments. It has been reported ${ }^{43}$ that the $2 v$ overtone band of isolated silanol groups on the dehydrated silica surface red shifts by $100-150 \mathrm{~cm}^{-1}$ owing to the formation of the $\mathrm{Si}-\mathrm{OH} \cdots \mathrm{OH}_{2}$ adduct upon the adsorption of water. Thus, most of the hydroxyls exhibiting the band at $7231 \mathrm{~cm}^{-1}$ may be associated with the methoxy perturbed $\mathrm{Si}-\mathrm{OH}$ hydroxyls, together with a small amount being contributed from the inaccessible $\mathrm{Si}-\mathrm{OH}$ hydroxyls $(\sim 26 \%)$. Interestingly, almost all the isolated $\mathrm{Si}-\mathrm{OH}$ hydroxyls on the $1 \% \mathrm{~V}_{2} \mathrm{O}_{5} / \mathrm{SiO}_{2}$ sample are affected by chemisorption of methanol, which is in contrast to the pure silica support, where only a very minor amount of

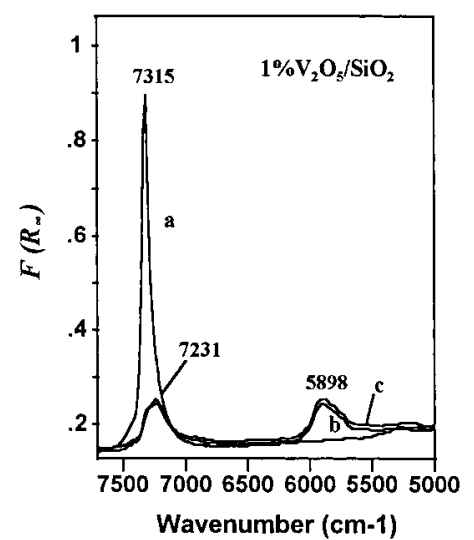

Figure 9. NIR DRS spectra of the $1 \% \mathrm{~V}_{2} \mathrm{O}_{5} / \mathrm{SiO}_{2}$ sample after (a) $\mathrm{O}_{2} / \mathrm{He}, 500{ }^{\circ} \mathrm{C}$; (b) $\mathrm{CH}_{3} \mathrm{OH} / \mathrm{O}_{2} / \mathrm{He}, 120{ }^{\circ} \mathrm{C}$; (c) $\mathrm{CH}_{3} \mathrm{OH} / \mathrm{O}_{2} / \mathrm{He}, 230$ ${ }^{\circ} \mathrm{C}$.
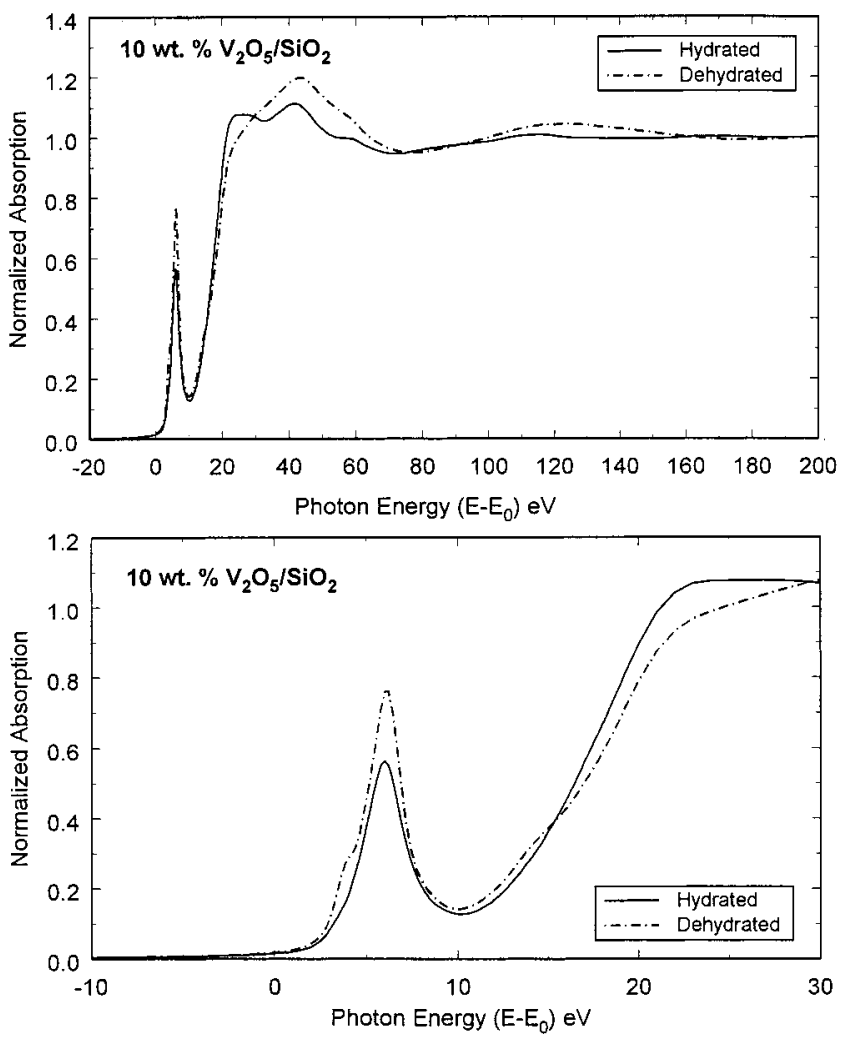

Figure 10. The V K-edge XANES spectra of the $10 \% \mathrm{~V}_{2} \mathrm{O}_{5} / \mathrm{SiO}_{2}$ sample in hydrated and dehydrated states.

$\mathrm{Si}-\mathrm{OH}$ hydroxyls are affected under the same experimental conditions. ${ }^{19}$ Somehow the deposition of even a small amount $\left(0.2 \mathrm{~V}\right.$ atoms $\left./ \mathrm{nm}^{2}\right)$ of surface vanadium oxide species on silica significantly modified the silica surface. This result also indicates that the surface vanadium oxide species are evenly dispersed over the entire silica surface. Methanol oxidation at $230{ }^{\circ} \mathrm{C}$ gives basically the same spectral feature.

4. X-ray Absorption Spectroscopy (XANES). The V $\mathrm{K}$-edge XANES spectra of the $10 \% \quad \mathrm{~V}_{2} \mathrm{O}_{5} / \mathrm{SiO}_{2}$ sample in hydrated and dehydrated states are presented in Figure 10. The upper panel shows the full $200 \mathrm{eV}$ XANES, and the lower panel is an enlargement of the preedge region. For comparison and energy calibration, the $\mathrm{V}$ K-edge XANES spectra of $\mathrm{V}_{2} \mathrm{O}_{5}$ and $\mathrm{NH}_{4} \mathrm{VO}_{3}$ reference compounds were also recorded (not shown here), which are in excellent agreement with those previously reported by Wong et al. ${ }^{44}$ and Yoshida et al. ${ }^{15}$ The energy positions of the main spectral features are summarized in Table 
TABLE 6: Energy Positions of the Preedge Peak, the Edge, and the $1 s \rightarrow 4 p$ Transition in the V K-Edge XANES Spectra

\begin{tabular}{lcccc}
\hline \multicolumn{1}{c}{ sample } & prepeak position $(\mathrm{eV})$ & prepeak height & \multicolumn{1}{c}{ edge $(\mathrm{eV})^{a}$} & $1 \mathrm{~s} \rightarrow 4 \mathrm{p} \mathrm{transition}(\mathrm{eV})$ \\
\hline $\mathrm{V}_{2} \mathrm{O}_{5}$ & $6.1(5.6)^{b}$ & 0.62 & $16.6(16.4)$ & $29.9(29.6)$ \\
$\mathrm{NH}_{4} \mathrm{VO}_{3}$ & $5.6(5.3)$ & 0.89 & $18.0(17.6)$ & $27.1(27.2)$ \\
$10 \% \mathrm{~V}_{2} \mathrm{O}_{5} / \mathrm{SiO}_{2}$ hydrated & $6.0(5.6)$ & 0.56 & ill-defined (16.7) & ill-defined (22.7) \\
$10 \% \mathrm{~V}_{2} \mathrm{O}_{5} / \mathrm{SiO}_{2}$ dehydrated & 6.0 & 0.76 & $18.9(18.2)$ & ill-defined
\end{tabular}

${ }^{a}$ Determined from the second maximum of the derivative XANES spectra (see Figure 11). ${ }^{b}$ The values in parentheses have been extracted from Yoshida et al. ${ }^{15}$ Their dispersed $\mathrm{V}_{2} \mathrm{O}_{5} / \mathrm{SiO}_{2}$ sample contains only 2.8 wt $\% \mathrm{~V}$.

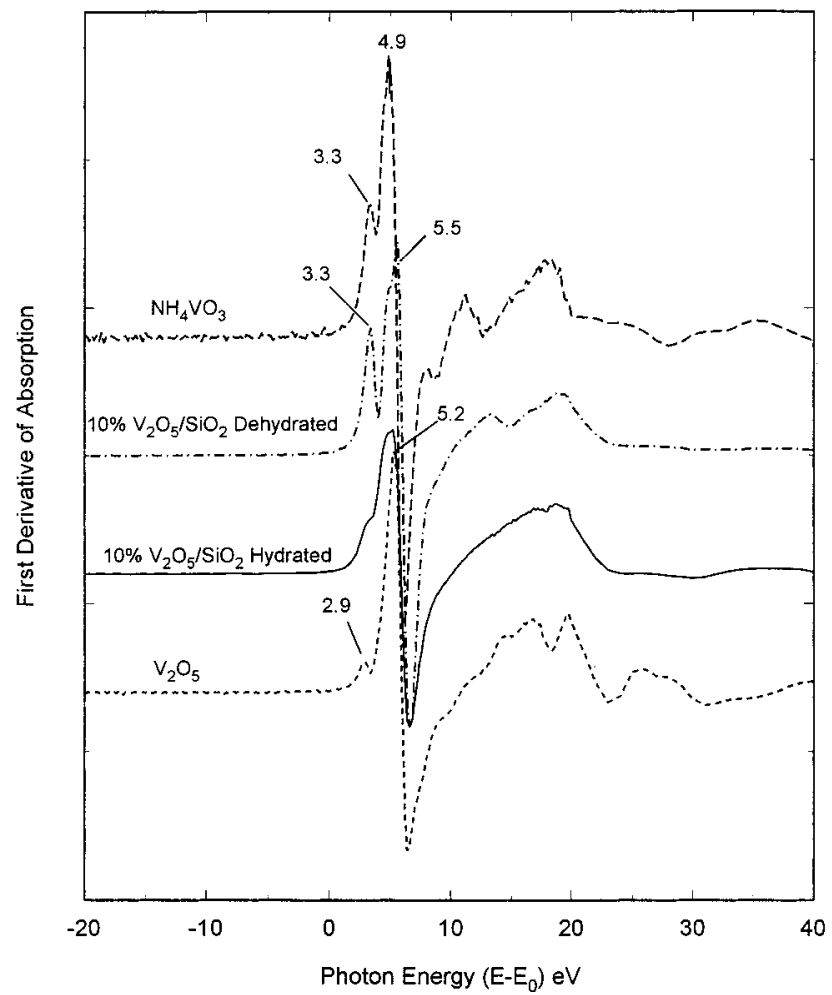

Figure 11. Derivative plots of the $\mathrm{V}$ K-edge spectra of $\mathrm{NH}_{4} \mathrm{VO}_{3}, \mathrm{~V}_{2} \mathrm{O}_{5}$, and the $10 \% \mathrm{~V}_{2} \mathrm{O}_{5} / \mathrm{SiO}_{2}$ sample.

6. Figure 11 shows a stack plot of the first derivative of the reference materials and catalysts to further illustrate the features in the XANES spectra.

The main characteristic feature in these XANES spectra is the so-called preedge peak. According to Wong et al. ${ }^{44}$ the preedge peak at $\sim 5 \mathrm{eV}$ is the dipole-forbidden transition $1 \mathrm{~s} \rightarrow$ $3 \mathrm{~d}$, which becomes allowed as a result of the removal of inversion symmetry around the $\mathrm{V}$ atom such that $3 \mathrm{~d}-4 \mathrm{p}$ mixing and overlap of the vanadium $3 \mathrm{~d}$ orbitals with the $2 \mathrm{p}$ orbitals of the oxygen occur. Thus, as the symmetry of the ligands around the $\mathrm{V}$ atom is lowered from perfect octahedral $\rightarrow$ distorted octahedral $\rightarrow$ square-pyramidal $\rightarrow$ tetrahedral, the preedge intensity increases dramatically, which has been used as a guide of the coordination of the $\mathrm{V}$ atom. For example, the preedge peak is much more intense in $\mathrm{NH}_{4} \mathrm{VO}_{3}\left(\mathrm{VO}_{4}\right.$ structure) than in $\mathrm{V}_{2} \mathrm{O}_{5}$ (distorted square-pyramidal $\mathrm{VO}_{5}$ structure) (see Table 6).

A significant increase in the preedge peak intensity of the $10 \% \quad \mathrm{~V}_{2} \mathrm{O}_{5} / \mathrm{SiO}_{2}$ sample was observed upon dehydration, together with significant changes in the overall XANES spectrum up to $200 \mathrm{eV}$ above the edge (see Figure 10 and Table 6 ). The position and relative height of the preedge peak in the dehydrated $10 \% \quad \mathrm{~V}_{2} \mathrm{O}_{5} / \mathrm{SiO}_{2}$ sample are quite comparable to those of $\mathrm{NH}_{4} \mathrm{VO}_{3}$. The XANES features of the dehydrated $10 \%$ $\mathrm{V}_{2} \mathrm{O}_{5} / \mathrm{SiO}_{2}$ sample are all consistent with the vanadium being present as $\mathrm{VO}_{4}$ units. However, these results cannot be used to distinguish isolated versus polymeric $\mathrm{VO}_{4}$ units for the dehydrated catalysts, but the data are in excellent agreement with the coordination determined by $\mathrm{UV}-\mathrm{vis}$ and Raman spectroscopy. For the hydrated $10 \% \mathrm{~V}_{2} \mathrm{O}_{5} / \mathrm{SiO}_{2}$ sample, it is interesting to note that the position and relative height of the preedge peak are comparable to those of $\mathrm{V}_{2} \mathrm{O}_{5}$, indicating a possible distorted square-pyramidal $\mathrm{VO}_{5}$ geometry. The XANES data presented here are in good agreement with the XANES data of Yoshida et al. ${ }^{15}$ who showed data for their highly dispersed $\mathrm{V}_{2} \mathrm{O}_{5} / \mathrm{SiO}_{2}$ catalyst with a low $\mathrm{V}$ content of 2.8 wt \% in both hydrated and dehydrated states.

An interesting feature in these XANES studies is the observation that there is a clear shoulder on the low-energy side of the prepeak in both catalysts and both reference compounds. This shoulder clearly manifests itself in the first derivatives shown in Figure 11. The observation of this feature has been noted by Wong et al., ${ }^{44}$ but to our knowledge it has not been assigned. It is much more intense in $\mathrm{NH}_{4} \mathrm{VO}_{3}$ and the dehydrated $10 \% \mathrm{~V}_{2} \mathrm{O}_{5} / \mathrm{SiO}_{2}$ sample with $\mathrm{VO}_{4}$ coordination than in $\mathrm{V}_{2} \mathrm{O}_{5}$ and the hydrated $10 \% \mathrm{~V}_{2} \mathrm{O}_{5} / \mathrm{SiO}_{2}$ sample with distorted $\mathrm{VO}_{5}$ coordination. This feature might be associated with the distortion of the structure from perfect geometry (e.g., $T_{d} \rightarrow$ distorted tetrahedra), which changes the distribution of the LUMO orbitals (mainly d in character), thus causing the splitting of $1 \mathrm{~s} \rightarrow 3 \mathrm{~d}$ transitions.

\section{Discussion}

Molecular Structures of Surface Vanadium Oxide Species on $\mathrm{SiO}_{2}$ in the Dehydrated State. The main dispute about the molecular structure of the dehydrated, dispersed $\mathrm{V}_{2} \mathrm{O}_{5} / \mathrm{SiO}_{2}$ catalysts focuses at high vanadia loadings: whether only isolated $\mathrm{VO}_{4}$ species are present or some polymerized $\mathrm{V}-\mathrm{O}-\mathrm{V}$ species are also present or even dominant on the silica surface. In this work, the maximum coverage of the dispersed vanadium oxide species on silica was achieved at $\sim 12 \% \mathrm{~V}_{2} \mathrm{O}_{5}$ loading $(\sim 2.6 \mathrm{~V}$ atoms $/ \mathrm{nm}^{2}$ ). Up to this maximum coverage, Raman spectra of the dehydrated samples do not show vibrations in the regions of $900-500$ and $300-200 \mathrm{~cm}^{-1}$ due to the stretching and bending modes of the polymerized $\mathrm{V}-\mathrm{O}-\mathrm{V}$ species, respectively. ${ }^{45}$ In addition, UV-vis spectra demonstrate that the edge energy only has a minor change from 3.6 to $3.4 \mathrm{eV}$ as the vanadia loading increases from $1 \%$ to $12 \%$, and this slight decrease in energy may be only associated with the slight change in structural distortion owing to the increase of $\mathrm{V}$ atomic density on the silica surface. Moreover, the dehydrated surface vanadium oxide species on silica exhibit one LMCT band centered at $278-298 \mathrm{~nm}$, which could be arbitrarily deconvoluted into two or more bands. Hazenkamp et al. ${ }^{46}$ assigned two bands at $34000 \mathrm{~cm}^{-1}(294 \mathrm{~nm})$ and $39400 \mathrm{~cm}^{-1}(254 \mathrm{~nm})$ to the $1 \mathrm{~A}_{1} \rightarrow 1 \mathrm{E}$ and $1 \mathrm{~A}_{1} \rightarrow 2 \mathrm{~A}_{1}$ transitions (from orbitals mainly consisting of oxygen $2 \mathrm{p}$-orbitals to vanadium $3 \mathrm{~d}$-orbitals). Tran et al. ${ }^{47}$ proposed that for the $(\mathrm{SiO})_{3} \mathrm{~V}=\mathrm{O}\left(C_{3 v}\right)$ group, the $\mathrm{HOMO}$ $\mathrm{a}_{2}$ orbital is a nonbonding orbital localized on the basal plane oxygen ligands and the LUMO $\mathrm{e}^{*}$ orbital is an antibonding $\pi^{*}$ orbital. The lowest LMCT transition results from $\mathrm{a}_{2}$ to $\mathrm{e}^{*}$ orbital $\left[{ }^{1} \mathrm{~A}_{1} \rightarrow{ }^{3} \mathrm{E}\right]$, and some other transitions such as the two singlet transitions at $290 \mathrm{~nm}\left[{ }^{1} \mathrm{~A}_{1} \rightarrow{ }^{1} \mathrm{~A}_{1}\right](\mathrm{a}$ " $\pi \rightarrow \mathrm{p} *$ * $\mathrm{V}=\mathrm{O}$ transition $)$ 
and $240 \mathrm{~nm}\left[{ }^{1} \mathrm{~A}_{1} \rightarrow{ }^{1} \mathrm{E}\right]$ may also occur. These electronic transitions give rise to the overlapping bands in the region of 200-400 $\mathrm{nm}$. Therefore, the LMCT transitions centered at 278-298 $\mathrm{nm}$ for the dehydrated surface vanadium oxide species on silica may originate from the isolated $\mathrm{VO}_{4}$ species up to maximum coverage of $12 \% \mathrm{~V}_{2} \mathrm{O}_{5}\left(2.6 \mathrm{~V}\right.$ atoms $\left./ \mathrm{nm}^{2}\right)$.

It is interesting to note that deposition of vanadium oxide species on the silica surface significantly decreases the concentration of tricyclosiloxane (three-member) rings that exhibit a Raman band at $\sim 607 \mathrm{~cm}^{-1}$. This result suggests that the chemical bonding between the $\mathrm{V}(\mathrm{V})$ cations and the silica surface somehow destroys this type of siloxane rings. These three-member rings with strained structure can easily be hydrolyzed into isolated, vicinal silanol groups by chemisorbed water molecules. Inumaru et al. ${ }^{11}$ reported that the surface reaction of $\mathrm{V}$-ethoxide with the silica surface produces dominantly $(\mathrm{Si}-\mathrm{O})_{2} \mathrm{VO}\left(\mathrm{OC}_{2} \mathrm{H}_{5}\right)$ species $(72 \%-82 \%)$ for silica pretreated at $250{ }^{\circ} \mathrm{C}$. Thus, the pretreatment temperature of $120^{\circ} \mathrm{C}$ in this work may give rise to a higher fraction of $(\mathrm{Si}-$ $\mathrm{O})_{2} \mathrm{VO}\left(\mathrm{OCH}_{3}\right)$ species. The formation of a $(\mathrm{Si}-\mathrm{O})_{2} \mathrm{VO}\left(\mathrm{OCH}_{3}\right)$ complex requires two vicinal $\mathrm{Si}-\mathrm{OH}$ groups, which can be provided by the hydrolyzed three-member rings. The maximum experimental concentration of three-member rings on the amorphous $\mathrm{SiO}_{2}$ surface obtained after vacuum annealing at 650 ${ }^{\circ} \mathrm{C}$ is estimated to be $2.2-4.5 / \mathrm{nm}^{2} .48$ Thus, the three-member rings are thought to be the most favorable sites for anchoring $\mathrm{V}(\mathrm{V})$ cations since this specific type of silica ring provides two vicinal $\mathrm{Si}-\mathrm{OH}$ hydroxyls after hydrolysis. The total amount of surface $\mathrm{Si}-\mathrm{OH}$ hydroxyls on silica after pretreatment at 100 ${ }^{\circ} \mathrm{C}$ is estimated to be $4-5 \mathrm{OH} / \mathrm{nm}^{2} .{ }^{49}$ Both Raman and NIR DRS experiments show that the surface $\mathrm{Si}-\mathrm{OH}$ hydroxyls are almost completely consumed by deposition of the surface vanadium oxide species at maximum coverage of $\sim 2.6 \mathrm{~V}$ atoms/ $\mathrm{nm}^{2}$. The maximum $\mathrm{Si}-\mathrm{O}^{-}$ligands needed for anchoring the $\mathrm{V}$ atoms at maximum coverage is about $7.8 \mathrm{Si}-\mathrm{O}$ groups $/ \mathrm{nm}^{2}$, which is higher than the total amount of the surface $\mathrm{Si}-\mathrm{OH}$ hydroxyls during impregnation. Therefore, some $\mathrm{Si}-\mathrm{O}-\mathrm{Si}$ siloxane bridges must be broken during calcination for the formation of the three-legged $\mathrm{VO}_{4}$ species, which is further supported by the Raman results.

Above the maximum coverage, crystalline $\mathrm{V}_{2} \mathrm{O}_{5}$ particles were detected for the dehydrated $15 \% \quad \mathrm{~V}_{2} \mathrm{O}_{5} / \mathrm{SiO}_{2}$ sample by both Raman and UV-vis spectroscopies. Strong, broad Raman bands are observed between 600 and $400 \mathrm{~cm}^{-1}$ in addition to the bands due to crystalline $\mathrm{V}_{2} \mathrm{O}_{5}$. The presence of static disorder in a crystal-like phase, such as the trapping of some water molecules between layers of crystalline $\mathrm{V}_{2} \mathrm{O}_{5}$, can give rise to band broadening and relative intensity changes. ${ }^{27 b}$ The strong, broad bands between 600 and $400 \mathrm{~cm}^{-1}$ may be associated with poorly crystallized $\mathrm{V}_{2} \mathrm{O}_{5}$ species that interact with the silica surface. The LMCT absorption at $410 \mathrm{~nm}$ for the dehydrated $15 \% \quad \mathrm{~V}_{2} \mathrm{O}_{5} / \mathrm{SiO}_{2}$ sample also supports the presence of poorly crystallized $\mathrm{V}_{2} \mathrm{O}_{5}$ species with a polymerized $\mathrm{VO}_{5} / \mathrm{VO}_{6}$ structure, which may possess some differences in local environment than $\mathrm{V}_{2} \mathrm{O}_{5}$ crystallites. It is speculated that at vanadia loadings higher than the maximum dispersion, some two-dimensional (2D) layered $\mathrm{V}_{2} \mathrm{O}_{5}$ patches somehow interacting with the silica surface might coexist with the crystalline $\mathrm{V}_{2} \mathrm{O}_{5}$ particles.

Molecular Structures of Surface Vanadium Oxide Species on $\mathrm{SiO}_{2}$ in Hydrated States. Before discussion of the molecular structure of hydrated vanadium oxide species on silica, it is necessary to understand the molecular structure of the $\mathrm{VO}_{x}$ species in the red transparent solution that was extracted

\section{CHART 1}

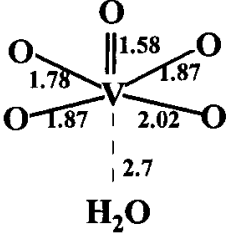

(a)

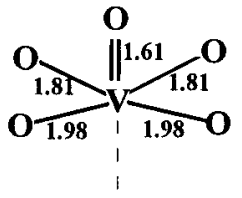

(b) from the dispersed $\mathrm{V}_{2} \mathrm{O}_{5} / \mathrm{SiO}_{2}$ sample. These results can provide a better understanding about the molecular structure of the original, hydrated surface vanadium oxide species on silica, which exhibits similar color and Raman spectra. The Raman results indicate that the aqueous $\mathrm{VO}_{x}$ species is one type of $\mathrm{V}_{2} \mathrm{O}_{5} \cdot n \mathrm{H}_{2} \mathrm{O}$ gels, and the deep red, hydrated surface vanadium oxide species on silica possess a structure more similar to $\mathrm{V}_{2} \mathrm{O}_{5}$. $n \mathrm{H}_{2} \mathrm{O}$ gels than $\mathrm{V}_{2} \mathrm{O}_{5}$ crystallites.

The local structure of $\mathrm{V}_{2} \mathrm{O}_{5} \cdot n \mathrm{H}_{2} \mathrm{O}$ gels has been discussed in a review paper by Livage. ${ }^{50}$ Regardless of the number of water molecules in the gel structure, vanadium is always in a distorted square-pyramidal $\mathrm{VO}_{5}$ environment with one short $\mathrm{V}=$ $\mathrm{O}$ double bond at a distance of $\sim 1.6 \AA$ as in crystalline $\mathrm{V}_{2} \mathrm{O}_{5}$. In addition, vanadium also possesses a long $\mathrm{V}-\mathrm{O}$ bond at a distance of $\sim 2.7 \AA$ under the pyramidal base. Therefore, the local structure of vanadium in either $\mathrm{V}_{2} \mathrm{O}_{5} \cdot n \mathrm{H}_{2} \mathrm{O}$ gels or $\mathrm{V}_{2} \mathrm{O}_{5}$ crystallites can also be regarded as a highly distorted $\mathrm{VO}_{6}$ structure. For $n=0.6$, the $\mathrm{V}_{2} \mathrm{O}_{5}$ layers are not connected through the interlayered long $\mathrm{V}-\mathrm{O}$ bonds but are coordinated to $\mathrm{H}_{2} \mathrm{O}$ molecules, which results in the formation of independent $2 \mathrm{D}$ layers. ${ }^{27}$ EXAFS studies ${ }^{51}$ show that in the $\mathrm{V}_{2} \mathrm{O}_{5} \cdot 1.6 \mathrm{H}_{2} \mathrm{O}$ gel, a water molecule is located at the opposite side of the $\mathrm{V}=$ O double bond with a bond length of $2.7 \AA$, as shown in Chart 1a. Solid state ${ }^{51} \mathrm{~V}$ NMR experiments suggest that in the red xerogels $\mathrm{V}_{2} \mathrm{O}_{5} \cdot 1.8 \mathrm{H}_{2} \mathrm{O}$ the mean $\mathrm{V}-\mathrm{O}$ bond length of the $\mathrm{V}(\mathrm{V})$ in distorted square-pyramidal is about $1.83 \AA \mathrm{A}^{35}$ in agreement with the EXAFS results. These studies indicate that vanadium oxide can form a independent 2D layer.

The present XANES study of the hydrated surface vanadium oxide species indicates a possible distorted square-pyramidal $\mathrm{VO}_{5}$ coordination, which is inconsistent with the XANES/ EXAFS studies by Yoshida et al. ${ }^{15}$ The local structure suggested by their EXAFS results is illustrated in Chart $1 \mathrm{~b}$. The bond lengths of 1.81 and $1.98 \AA$ might be related to the two $\mathrm{V}-\mathrm{OH}-\mathrm{V}$ bridging bond lengths, respectively. In analogy to $\mathrm{V}_{2} \mathrm{O}_{5} \cdot n \mathrm{H}_{2} \mathrm{O}$ gels, the $\mathrm{V}$ cations in the fully hydrated surface vanadium oxide species may share corners and edges to form chain polymers and/or a 2D layer, as shown in Figure 12F. The $\mathrm{V}=\mathrm{O}$ double bond in this structure exhibits a broad Raman band centered at $\sim 1020 \mathrm{~cm}^{-1}$, which corresponds to a bond length of $1.586 \AA$ as estimated from the correlation established by Hardcastle and Wachs. ${ }^{26}$ The surface vanadium oxide concentration appears to slightly affect the structural configuration of the hydrated vanadium oxide species by varying $\mathrm{V}-\mathrm{OH}-\mathrm{V}$ bridging bond lengths since Raman experiments show that some frequencies shift upward with increasing vanadia loading.

The molecular structure of the hydrated surface vanadium oxide species is apparently a strong function of the degree of hydration. There is no information concerning the hydrolysis rate of the $\mathrm{V}-\mathrm{O}-\mathrm{Si}$ bridges, which is a critical factor in determining the partially hydrated structures of the surface vanadium oxide species. The partial hydration of the dehydrated, dispersed $\mathrm{V}_{2} \mathrm{O}_{5} / \mathrm{SiO}_{2}$ sample results in a light yellow color with an edge energy between the dehydrated and fully hydrated states, suggesting that the degree of polymerization 


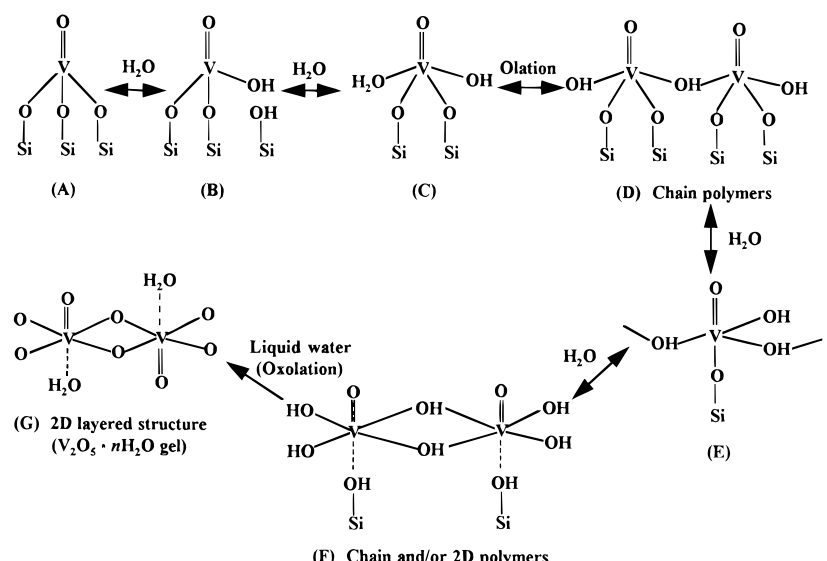

Figure 12. Hydration process proposed for surface vanadium oxide species on silica.

of the V cations is low and/or their coordination is less than 6 . The Raman spectrum shown in Figure $3 \mathrm{a}$ is associated with some partially hydrated surface vanadium oxide species. The Raman bands above $1000 \mathrm{~cm}^{-1}$, which are characteristic of $\mathrm{V}=\mathrm{O}$ double bonds, are broad and range from 1010 to 1035 $\mathrm{cm}^{-1}$, suggesting that $\mathrm{V}(\mathrm{V})$ sites with different local environments are present after partial hydration. Another Raman band observed at $915 \mathrm{~cm}^{-1}$ is also high enough to be characteristic of $\mathrm{V}=\mathrm{O}$ double bonds, which might be assigned to $\mathrm{V}=\mathrm{O}$ stretching coordinated with the $\mathrm{H}_{2} \mathrm{O}$ molecule $\left(\mathrm{H}_{2} \mathrm{O}-\mathrm{V}=\mathrm{O}\right)$, as in the case of $\mathrm{V}_{2} \mathrm{O}_{5} \cdot n \mathrm{H}_{2} \mathrm{O}$ gels. ${ }^{27}$ Moreover, for $\mathrm{V}_{2} \mathrm{O}_{5} \cdot n \mathrm{H}_{2} \mathrm{O}$ gels, the Raman band at $350-325 \mathrm{~cm}^{-1}$ is due to both a $v(\mathrm{~V}-$ $\mathrm{OH}_{2}$ ) stretching mode and a $\delta(\mathrm{VO})$ bending mode. Similarly, the broad $320 \mathrm{~cm}^{-1}$ band observed for the partially hydrated surface vanadium oxide species on silica may also be partly associated with the $v\left(\mathrm{~V}-\mathrm{OH}_{2}\right)$ stretching mode. Both the 915 and $320 \mathrm{~cm}^{-1}$ bands strongly suggest that some $\mathrm{V}(\mathrm{V})$ cations are bonded to $\mathrm{H}_{2} \mathrm{O}$ molecules. In addition, a low-degree polymerization of the hydrolyzed $\mathrm{V}(\mathrm{V})$ sites also occurs as evidenced by the Raman bands at 694, 647, and $493 \mathrm{~cm}^{-1}$ owing to the $\mathrm{V}-\mathrm{O}-\mathrm{V}$ stretching modes. Thus, depending on the degree of hydration, surface vanadium oxide species with different local structures could be formed.

On the present experimental results and the structural similarity to $\mathrm{V}_{2} \mathrm{O}_{5} \cdot n \mathrm{H}_{2} \mathrm{O}$ gels, the hydration process of the dehydrated surface vanadium oxide species on silica is proposed in Figure 12. The hydration appears to proceed through chemisorption of water molecules and hydrolysis of $\mathrm{V}-\mathrm{O}-\mathrm{Si}$ bridging bonds. The formation of $\mathrm{V}-\mathrm{OH}$ groups allows the polymerization of surface $\mathrm{V}(\mathrm{V})$ cations via olation along the $\mathrm{H}_{2} \mathrm{O}-\mathrm{V}-\mathrm{OH}$ direction, in analogy to the condensation process of $\mathrm{VO}(\mathrm{OH})_{3} .{ }^{50}$ Full hydration may break all the $\mathrm{V}-\mathrm{O}-\mathrm{Si}$ bridging bonds, resulting in the maximum polymerization between $\mathrm{VO}_{5}$ units. Consequently, a $2 \mathrm{D}$ layered structure, most likely bridged by $\mathrm{OH}$ groups, may be formed. The $\mathrm{Si}-\mathrm{OH}$ groups may serve as the binding sites to stabilize the 2D layered structure on the silica surface via hydrogen bonding. Up to this step, the hydration induced polymerization process is still reversible, and the isolated $\mathrm{VO}_{4}$ structure can be obtained after dehydration at elevated temperatures. However, with large quantities of water molecules around the surface, they can compete and substitute for the $\mathrm{Si}-\mathrm{OH}$ groups as the binding sites on the 2D layered structure. Once the $\mathrm{VO}_{x}$ species leave the silica surface by breaking the $\mathrm{V} \cdot \cdot \mathrm{OH}-\mathrm{Si}$ hydrogen bonds, oxolation occurs to form $\mathrm{V}_{2} \mathrm{O}_{5} \cdot n \mathrm{H}_{2} \mathrm{O}$ gels with $\mathrm{V}-\mathrm{O}-\mathrm{V}$ connections. The final process is irreversible.
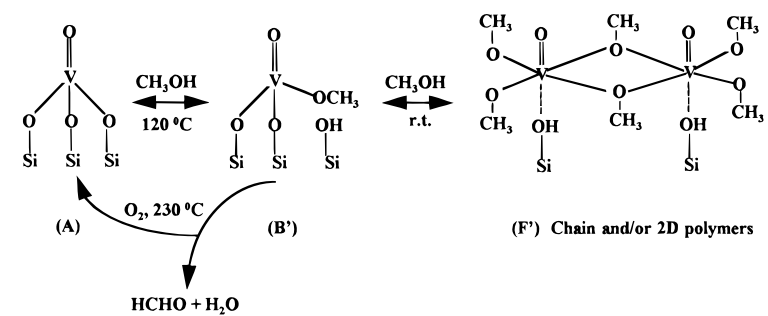

Figure 13. Interaction of methanol molecules with surface vanadium oxide species on silica.

Molecular Structures of Surface Vanadium Oxide Species on $\mathrm{SiO}_{2}$ under Methanol Chemisorption/Oxidation Reaction Conditions. The studies of methanol chemisorption are more relevant to the catalytic behavior of dispersed $\mathrm{V}_{2} \mathrm{O}_{5} / \mathrm{SiO}_{2}$ catalysts since the $\mathrm{V}(\mathrm{V})$ sites usually act as the active sites for various oxidation reactions. The interaction of methanol molecules with the surface vanadium oxide species on silica at room temperature is quite similar to that of water molecules. The surface vanadium oxide species on the $1 \% \quad \mathrm{~V}_{2} \mathrm{O}_{5} / \mathrm{SiO}_{2}$ sample, when saturated with methanol at room temperature (see Figure 8), exhibit very similar LMCT transitions as the fully hydrated sample. Its edge energy is also very close to that of the fully hydrated sample. The results suggest that the surface vanadium oxide species, when fully saturated with methanol, may possess a similar local structure as the fully hydrated vanadium oxide species. For pure vanadium methoxide, $\mathrm{VO}\left(\mathrm{OCH}_{3}\right)_{3}$, the vanadium atom is in distorted octahedral coordination and the octahedra are joined together into polymer chains by sharing edges. ${ }^{52}$ Since the surface V-methoxy complexes on silica are polymerized $\mathrm{VO}_{6}$ units, the $\mathrm{V}(\mathrm{V})$ cations may be connected together into chain and/or $2 \mathrm{D}$ polymers by sharing an edge and/or corner of $-\mathrm{OCH}_{3}-$ groups, depending on the surface concentration of $\mathrm{V}(\mathrm{V})$ cations, as shown in Figure $13 \mathrm{~F}^{\prime}$. This structure is quite similar to the fully hydrated vanadium oxide species shown in Figure 12F. Higher loading samples $\left(\geq 5 \% \quad \mathrm{~V}_{2} \mathrm{O}_{5}\right)$ provide essentially similar experimental results, but slight reduction occurs simultaneously during the formation of the surface V-methoxy species even at room temperature in the reaction feed stream.

Increasing methanol chemisorption temperature to $120^{\circ} \mathrm{C}$ and above removes the physisorbed methanol molecules and changes the molecular structure of the surface vanadium oxide species. In situ Raman results demonstrate that $\left(\mathrm{CH}_{3} \mathrm{O}\right)-\mathrm{V}=\mathrm{O}$ methoxy species are formed on the silica surface during methanol oxidation. In addition, $\mathrm{UV}-$ vis DRS results indicate that the $\mathrm{V}$-methoxy species formed at 120 and $230{ }^{\circ} \mathrm{C}$ are an isolated $\mathrm{VO}_{4}$ structure, and some $\mathrm{SiO}^{-}$ligands in the coordination sphere of the $\mathrm{V}(\mathrm{V})$ cations are replaced by $\mathrm{CH}_{3} \mathrm{O}^{-}$ligands. One possible structure is illustrated in Figure 13B', which is very likely the intermediate structure for the production of formaldehyde at the reaction temperature of $230{ }^{\circ} \mathrm{C}$ and above since dispersed $\mathrm{V}_{2} \mathrm{O}_{5} / \mathrm{SiO}_{2}$ catalysts produce predominantly formaldehyde during methanol oxidation. However, it is not clear from Raman and $\mathrm{UV}-$ vis DRS results how many $\mathrm{SiO}^{-}$ligands can be substituted by $\mathrm{CH}_{3} \mathrm{O}^{-}$. It is possible that all three $\mathrm{V}-\mathrm{O}-$ $\mathrm{Si}$ bridging bonds can be broken by methanol chemisorption since aggregation of surface V-methoxy species on silica was observed at high vanadia loadings $(\geq 5 \%)$ and some volatile $\mathrm{V}$-methoxy species were produced during methanol oxidation at $230{ }^{\circ} \mathrm{C}$.

\section{Conclusions}

The molecular structure of the surface vanadium oxide species on silica is a strong function of environmental conditions. In 
the dehydrated state, the isolated $\mathrm{VO}_{4}$ species are unique up to monolayer coverage of $\sim 12$ wt $\% \mathrm{~V}_{2} \mathrm{O}_{5}\left(\sim 2.6 \mathrm{~V}\right.$ atoms $\left./ \mathrm{nm}^{2}\right)$. The deposition of surface vanadium oxide species consumes most of the surface $\mathrm{Si}-\mathrm{OH}$ hydroxyls and breaks some surface $\mathrm{Si}-\mathrm{O}-\mathrm{Si}$ siloxane bridges. The three-member rings on silica appear to be the most favorable sites for anchoring the isolated, three-legged $(\mathrm{SiO})_{3} \mathrm{~V}=\mathrm{O}$ units. Above monolayer coverage, $\mathrm{V}_{2} \mathrm{O}_{5}$ crystallites are formed, possibly with some poorly crystallized $2 \mathrm{D} \mathrm{V}_{2} \mathrm{O}_{5}$ patches that possess some interaction with the silica surface. Hydration dramatically changes the molecular structure of the surface vanadium oxide species, and the degree of hydration plays a critical role in determining the specific structure of the vanadium oxide species on the silica surface. During the hydration process, hydrolysis of $\mathrm{V}-\mathrm{O}-\mathrm{Si}$ bonds occurs and $\mathrm{V}(\mathrm{V})$ cations may form chain polymers via olation. Full hydration results in maximum polymerization to form chain and/or $2 \mathrm{D}$ polymers most likely through $\mathrm{V}-\mathrm{OH}-\mathrm{V}$ bridges. $\mathrm{V}_{2} \mathrm{O}_{5} \cdot n \mathrm{H}_{2} \mathrm{O}$ gels with independent $2 \mathrm{D}$ layers can simply be obtained by adding liquid water to the dispersed $\mathrm{V}_{2} \mathrm{O}_{5} / \mathrm{SiO}_{2}$ samples.

Upon saturation with methanol molecules at room temperature, the surface vanadium oxide species may form chain and/ or $2 \mathrm{D}$ polymers through $\mathrm{V}-\mathrm{OCH}_{3}-\mathrm{V}$ bridges on the silica surface. Methanol chemisorption at high temperatures $(\geq 120$ ${ }^{\circ} \mathrm{C}$ ) results in isolated, 4-fold coordinated V(V)-methoxy species, which may serve as an intermediate for methanol oxidation. Moreover, alcoholysis of the $\mathrm{V}-\mathrm{O}-\mathrm{Si}$ bonds destabilizes the surface vanadium oxide species, which results in the aggregation of the surface vanadium oxide species on silica and production of some volatile $\mathrm{V}$-methoxy species during methanol oxidation at high temperatures.

Acknowledgment. This work was funded by the U.S. National Science Foundation Grant CTS-9417981. The UVvis-NIR DRS experiments were performed on a Varian Cary 5 UV-vis-NIR spectrometer that was supported by the U.S. Department of Energy, Basic Energy Sciences, Grant DE-FG0293ER14350. Part of the research was carried out at the National Synchrotron Light Source, Brookhaven National Laboratory, which is supported by the U.S. Department of Energy, Division of Materials Sciences and Division of Chemical Sciences. The authors thank Dr. M. A. Banares for the help with BET surface area measurements and chemical analysis.

\section{References and Notes}

(1) Sun, Q.; Jehng, J. M.; Hu, H. H.; Herman, R. G.; Wachs, I. E.; Klier, K. J. Catal. 1997, 165, 91.

(2) Irusta, S.; Cornaglia, L. M.; Miro, E. E.; Lombardo, E. A. J. Catal. 1995, 156, 167.

(3) Banares, M.; Gao, X.; Fierro, J. L. G.; and Wachs, I. E. Stud. Surf. Sci. Catal. 1997, 110, 295.

(4) Tanaka, T.; Nishimura, S.; Kawasaki, S.; Ooe, M.; Funabiki, T.; Yoshida, S. J. Catal. 1989, 118, 327.

(5) Kaliaguine, S. L.; Shelimov, B. N.; Kazansky, V. B. J. Catal. 1978, 55,384

(6) Anpo, M.; Sunamoto, M.; Che, M. J. Phys. Chem. 1989, 93, 1187.

(7) Jonson, B.; Rebenstrof, B.; Larsson, R.; Andersson, S. L. J. Chem. Soc., Faraday Trans. 1 1988, 84, 1897.

(8) Lische, G.; Hanke, W.; Jerschkewitz, H. G.; Ohlmann, J. J. Catal. 1985, 91,54 .

(9) Iwamoto, M.; Hirata, J.; Matsukami, K.; Kagawa, S. J. Phys. Chem. 1983, 87, 903.

(10) (a) Schraml-Marth, M.; Wokaun, A.; Pohl, M.; Krauss, H.-L. J. Chem. Soc., Faraday Trans. 1991, 87, 2635. (b) Scharf, U.; Schraml-Marth, M.; Wokaun, Baiker, A. J. Chem. Soc., Faraday Trans. 1991, 87, 3299.

(11) (a) Inumaru, K.; Okuhara, T.; Misono, M.; Matsubayashi, N.; Shimada, H.; Nishijima, A. J. Chem. Soc., Faraday Trans. 1992, 88, 625. (b) Inumaru, K.; Okuhara, T.; Misono, M. J. Phys. Chem. 1991, 95, 4826. (c) Inumaru, K.; Misono, M.; Okuhara, T. Appl. Catal. A, 1997, 149, 133.
(12) Das, N.; Eckert, H.; Hu, H.; Wachs, I. E.; Walzer, J. F.; Feher, F. J. J. Phys. Chem. 1993, 97, 8240. 4240 .

(13) Went, G. T.; Oyama, S. T.; Bell, A. T. J. Phys. Chem. 1990, 94,

(14) Roozeboom, F.; Mittelmeljer-Hazeleger, M. C.; Moulijn, J. A.; Medema, J.; de Beer, V. H. J.; Gellings, P. J. J. Phys. Chem. 1980, 84 2783.

(15) (a) Yoshida, S.; Tanaka, T.; Nishimura, Y.; Mizutani, H.; Funabiki, T. the Proc. 9th Int. Congr. Catal. 1988, 3, 1473. (b) Yoshida, S.; Tanaka, T.; Hanada, T.; Hiraiwa, T.; Kanai, H.; Funabiki, T. Catal. Lett. 1992, 12, 277. (c) Tanaka, T.; Yamashita, H.; Tsuchitani, R.; Funabiki, T.; Yoshida, S. J. Chem. Soc., Faraday Trans. 1 1988, 84, 2987.

(16) Arena, F.; Frusteri, F.; Martra, G.; Coluccia, S.; Parmaliana, A. J. Chem. Soc., Faraday Trans. 1997, 93, 3849.

(17) Hazenkamp, M. F.; Blasse, G. J. Phys. Chem. 1992, 96, 3442.

(18) Deo, G.; Wachs, I. E. J. Phys. Chem. 1991, 95, 5889.

(19) Gao, X.; Bare, R. S.; Fierro, J. L. G.; Banares, M.; Wachs, I. E. J. Phys. Chem. B 1998, 102, 5653

61 .

(20) Morrow, B. A.; Mcfarlan, A. J. J. Non-Cryst. Solids 1990, 120 ,

(21) Jehng, J. M.; Hu, H.; Gao, X.; Wachs, I. E. Catal. Today 1996 28,335

(22) Delgass, W. N.; Haller, G. L.; Kellerman, R.; Lunsford, J. H. Spectroscopy in Heterogeneous Catalysis; Academic Press: New York, 1979.

(23) (a) Tallant, D. R.; Bunker, B. C.; Brinker, C. J.; Balfe, C. A. Mater Res. Soc. Symp. Proc. 1986, 73, 261. (b) Stolen, R. H.; Walrafen, G. E. J. Chem. Phys. 1976, 64, 2623. (c) Brinker, C. J.; Tallant, D. R.; Roth, E. P.; Ashley, C. S. Mater. Res. Soc. Symp. Proc. 1986, 61, 387.

(24) Brinker, C. J.; Kirkpatrick, R. J.; Tallant, D. R.; Bunker, B. C.; Montez, B. J. Non-Cryst. Solids 1988, 99, 418.

(25) MacMillan, P. Am. Mineral. 1986, 69, 622.

(26) Hardcastle, F.; Wachs, I. E. J. Phys. Chem. 1991, 95, 5031.

(27) (a) Abello, L.; Husson, E.; Repelin, Y.; Lucazeau, G. J. Solid State Chem. 1985, 56, 379. (b) Repelin, Y.; Husson, E.; Abello, L.; Lucazeau, G. Spectrochim. Acta, 1985, 41A, 993.

(28) Ray, W. J.; Post, C. B. Biochemistry 1990, 29, 2779

(29) (a) Sanderson, R. T. J. Chem. Educ. 1988, 65, 113. (b) Sanderson, R. T. J. Chem. Educ. 1988, 65, 227. (c) Sanderson, R. T. Polar Covalence; Academic Press: New York, 1983.

(30) Jehng, J. M.; Deo, G.; Weckhuysen, B. M.; Wachs, I. E. J. Mol. Catal. 1996, 110, 41.

(31) Barraclough, C. G.; Bradley, D. C.; Lewis, J.; Thomas, I. M. J. Chem. Soc. 1961, 2601

(32) Wright, A. C. Philos. Mag. B 1984, 50, L23.

(33) Marumo, F.; Isobe, M.; Iwai, S.; Kondo, Y. Acta Crystallogr. 1974, B30, 1628.

(34) Evans, H. T. Z. Kristallogr. 1960, 114, 257.

(35) Nabavi, M.; Taulelle, F.; Sanchez, C.; Verdaguer, M. J. Phys. Chem. Solids 1990, 51, 1375.

(36) Ng, H. N.; Calvo, C. Can. J. Chem. 1972, 50, 3619.

(37) (a) Sam, D. S. H.; Soenen, V.; Volta, J. C. J. Catal. 1990, 123, 417. (b) Busca, G. Ricchiardi, G.; Sam, D. S. H.; Volta, J. C. J. Chem. Soc., Faraday Trans. 1994, 90, 1161.

(38) Gopal, R.; Calvo, C. Acta Crystallogr. 1974, B30, 2491.

(39) Krishnamachari, N.; Calvo, C. Can. J. Chem. 1971, 49, 1629.

(40) Khan, G. A.; Hogarth, C. A. J. Mater. Sci. 1991, 26, 412.

(41) Fiermans, L.; Vennik, J. Surf. Sci. 1971, 24, 541.

(42) Karvaly, B.; Hevesi, I. Z. Naturforsch. Teil A 1971, 26, 245.

(43) Klier, K.; Zettlemoyer, A. C. J. Colloid Interface Sci. 1977, 58 , 216.

(44) Wong, J.; Lytle, F. W.; Messmer, R. P.; Maylotte, D. H. Phys. Rev. B 1984, 30, 5596.

(45) Deo, G. Ph.D. Thesis, Lehigh University, 1992

(46) Hazenkamp, M. F.; van Duijneveldt, F. B.; Blasse, G. Chem. Phys. 1993, 169, 55.

(47) Tran, K.; Hanning-Lee, M. A.; Biswas, A.; Stiegman, A. E.; Scott, G. W. J. Am. Chem. Soc. 1995, 117, 2618.

(48) Brinker, C. J.; Brow, R. K.; Tallant, D. R.; Kirkpatrick, R. J. J. Non-Cryst. Solids 1990, 120, 26.

(49) Vansant, E. F.; Voort, P. V. D.; Vrancken, K. C. Stud. Surf. Sci. Catal. 1995, 93.

(50) Livage, J. Chem. Mater. 1991, 3, 578.

(51) Stizza, S.; Mancini, G.; Benfatto, M.; Natoli, C. R.; Garcia, J.; Bianconi, A. Phys. Rev. B 1989, 40, 12229.

(52) Charles, N.; Caughlan, N.; Smith, H. M.; Watenpaugh, K. Inorg. Chem. 1966, 12, 2131 . 